\title{
SUSANNE EGNELL
}

ANNA-KARIN IVERT

UNGDOMARS UPPLEVELSER

AV TRYGGHET OCH

OTRYGGHET I DEN

OFFENTLIGA MILJÖN

Områdeskunskap, vardagsrisker och undvikande-strategier
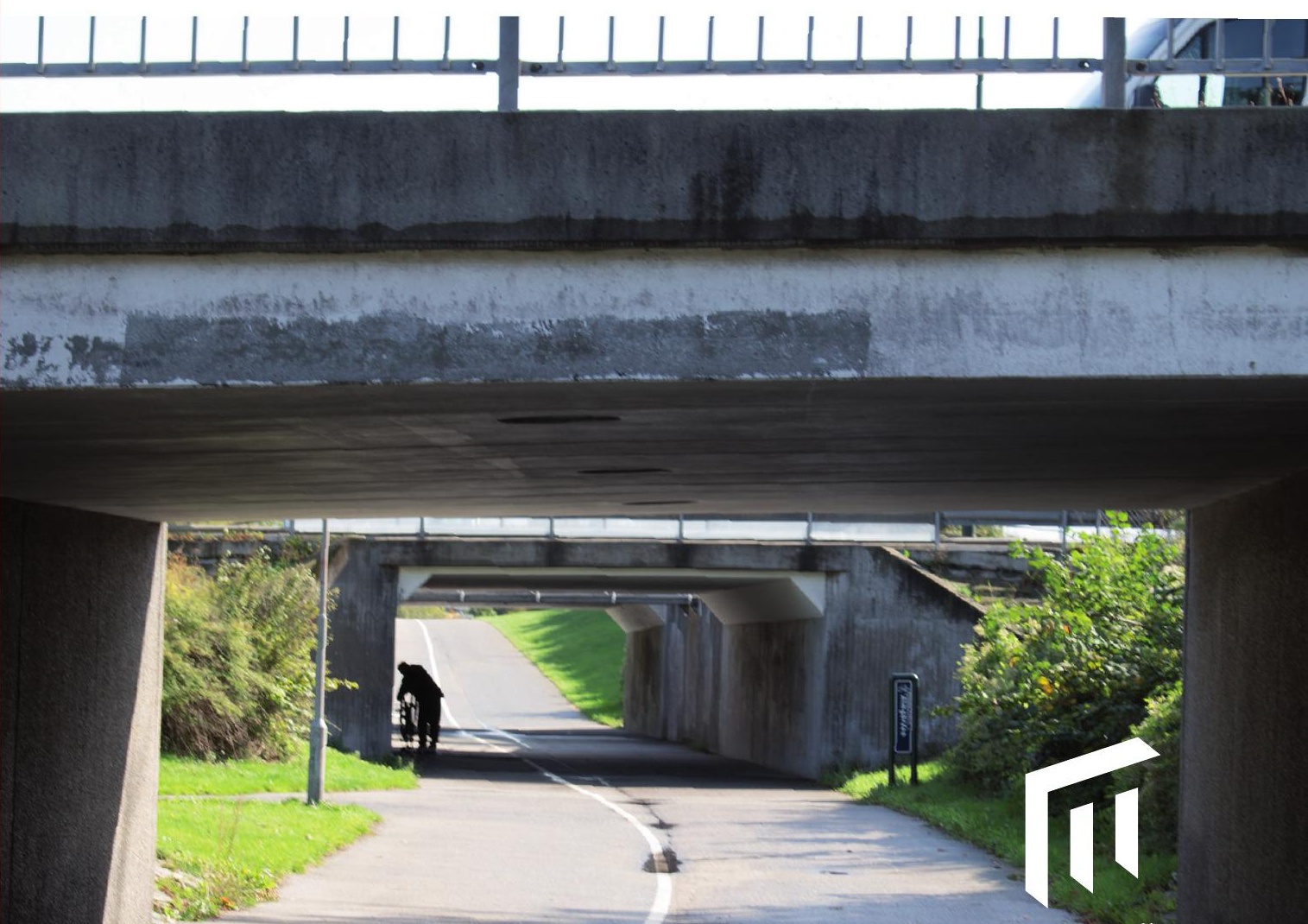

UNGDOMARS UPPLEVELSER AV TRYGGHET OCH OTRYGGHET I DEN OFFENTLIGA MILJÖN 
FoU rapport 2019:5

(C) Susanne Egnell \& Anna-Karin Ivert, 2019 Omslagsfoto: Rebecka Eriksson ISBN 978-9I-7877-04I-O (print)

ISBN 978-9I-7877-042-7 (pdf)

Holmbergs, Malmö 2019 


\section{SUSANNE EGNELL ANNA-KARIN IVERT UNGDOMARS UPPLEVELSER AV TRYGGHET OCH OTRYGGHET I DEN OFFENTLIGA MILJÖN}

Områdeskunskap, vardagsrisker och undvikande-strategier.

Malmö universitet, 2019

Institutionen för kriminologi Fakulteten för Hälsa och samhälle 



\section{INNEHÅLL}

FÖRORD .......................................................... 7

INTRODUKTION ............................................... 9

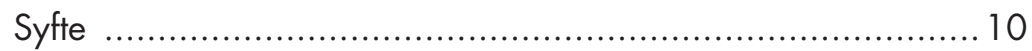

OTRYGGHET OCH UTSATTHET FÖR BROTT BLAND UNGA

- EN KUNSKAPSÖVERSIKT ................................ 11

Otrygghet bland ungdomar - betydelsen av området............... 12

Strategier och undvikanden........................................... 14

Ungdomar och utsatthet för brott ............................................ 16

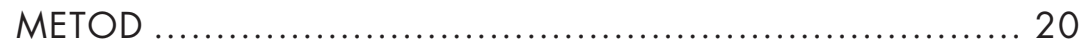

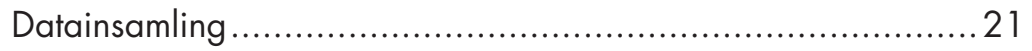

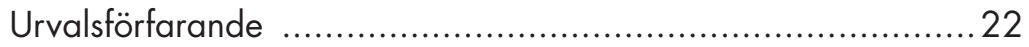

Databehandling och analytisk ansats ............................... 23

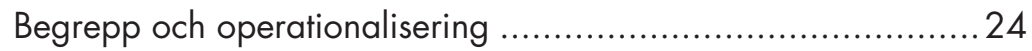

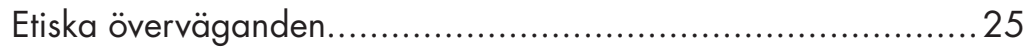

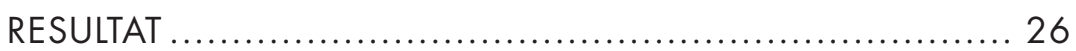

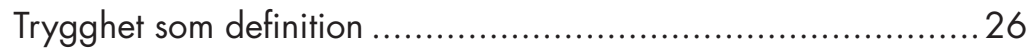

Ungdomars användning av och kunskap om sina områden .......27

Problembilden i Sofielund och Rosengård -en jämförelse ..........30

Ungdomars otrygghet - övergripande teman .........................35

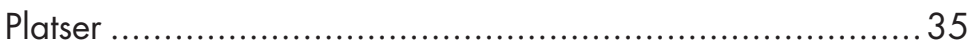

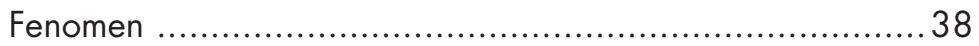

SAMMANFATTANDE DISKUSSION ......................... 48

Avslutande kommentarer .................................................. 53

LITTERATUR .................................................... 56 



\section{FÖRORD}

Den här rapporten bygger på intervjuer med ungdomar som bor, går i skolan eller av andra anledningar tillbringar mycket tid i två bostadsområden i Malmö som ofta beskrivs som utsatta områden med utbredda problem med otrygghet och kriminalitet. Det är områden som får mycket uppmärksamhet medialt och det är områden som de flesta Malmöbor känner till och har en åsikt om men kanske inte någon direkt erfarenhet av. Det är därför inte konstigt att de ungdomar vi intervjuat inledningsvis var skeptiska till vår forskning och frågade oss om varför vi alltid skulle fokusera på just deras områden, problem finns ju överallt. Frågan är försåtlig och viktig för oss som forskare att ta hänsyn till. Det har därför varit viktigt för oss att lägga tid vid att diskutera det, och förklara att centralt i vår forskning är att lyfta ungdomarnas berättelser och ge dem möjlighet att ge sina bilder av området. Vi hoppas att vi i den här rapporten kan göra just detta, att beskriva områdena utifrån ungdomarnas perspektiv och på så sätt bidra till en mer nyanserad bild av dessa områden.

Vi vill rikta ett stort tack till de ungdomar i Sofielund och Rosengård som deltagit i intervjuerna och delat med sig av sina erfarenheter och tankar. Vi vill också tacka fil. dr. Anne Harju som granskat rapporten och bidragit med värdefulla kommentarer.

Forskningen har genomförts med stöd från Allmänna Barnhuset, Stiftelsen Clas Groschinskys minnesfond Majblommans Riksförbund samt Malmö stad. 


\section{INTRODUKTION}

Inom ramen för de forskningsprojekt som ligger till grund för den här rapporten har vi velat undersöka ungdomars upplevelser och erfarenheter av otrygghet och oro att utsättas för brott i bostadsområdet. Mer specifikt har vi velat ta reda på hur ungdomar ser på trygghet och otrygghet, vilka problem med ordningsstörningar och kriminalitet de upplever finns i de områden där de bor eller går i skolan, samt om deras vardag på något sätt påverkas av deras trygghetsupplevelse. Vi har därför intervjuat ungdomar i åldrarna 14 till 22 år som bor eller går i skolan i Rosengård och Sofielund, två bostadsområden i Malmö. Bakgrunden till att just Sofielund och Rosengård valts ut är att områdena under en längre period haft problem med såväl kriminalitet som otrygghet. Delar av Rosengård (söder om Amiralsgatan) och Sofielund (Södra Sofielund, Seved) lyfts fram av Polismyndighetens Nationella operativa avdelning (NOA) som särskilt utsatta områden avseende bland annat påverkan av kriminella nätverk (Polisen, 2017). De båda områdena har även varit föremål för särskilda satsningar på nationell och lokal nivå som syftat till att öka tryggheten och skapa attraktiva bostadsområden.

Mycket av den kunskap vi idag har om hur upplevelsen av bostadsområdet hänger samman med människors trygghetsupplevelser bygger på vuxnas erfarenheter, och det finns ett betydande kunskapsgap avseende hur barns och ungdomars upplevelser och erfarenheter av närområdet påverkar deras upplevelser av (o)trygghet. Tidigare forskning visar att barns och ungdomars upplevelser av bostadsområdet hänger samman med hur de skattar sin psykiska hälsa (se t.ex. Aneshensel and Sucoff 1996; Ivert \& Torstensson Levander, 2014), och 
att dessa upplevelser i vissa fall är viktigare än områdets socioekonomiska förutsättningar. Kunskapen om hur, genom vilka mekanismer, upplevelsen av bostadsområdet påverkar barns och ungdomars hälsa är dock begränsad. En faktor som skulle kunna vara en bidragande orsak till sambandet är upplevd otrygghet. Eftersom en stor del av trygghetsforskningen - som redan påpekats - utgår ifrån och fokuserar på den vuxna befolkningens upplevelser av bostadsområden och andra offentliga platser och hur dessa upplevelser påverkar deras trygghetsupplevelse, finns ett behov att komplettera den kunskapen med forskning kring barns och ungdomars trygghetsupplevelse på offentlig och semi-offentlig plats ${ }^{1}$. Ett barn- och ungdomsperspektiv är en förutsättning för att kunna bedriva ett inkluderande trygghetsskapande arbete som - i så stor utsträckning som möjligt - tar hänsyn till allas behov. Det är viktigt att ta i beaktande att behoven kan skilja sig åt beroende på faktorer så som kön, ålder, funktion.

Den här rapporten bör ses som ett bidrag till ökad kunskap och förståelse för hur bostadsområdet påverkar den upplevda otryggheten bland barn och ungdomar. Vår förhoppning är att kunna skala upp studien längre fram genom att undersöka områden av annan karaktär och struktur, och komplettera med andra typer av datainsamlingsmetoder.

\section{Syfte}

Syftet med forskningsprojektet har varit att öka kunskapen kring ungdomars trygghetsupplevelser i Sofielund och Rosengård. Mer specifik syftar projektet till att undersöka hur ungdomarna beskriver den lokala problembilden och hur denna påverkar deras trygghetsupplevelse i den offentliga miljön, samt hur ungdomarnas beteende och rörelsemönster påverkas av otrygghet och oro för att utsättas för brott. Vissa jämförelser görs också mellan ungdomarna från de olika områdena för att belysa likheter och skillnader mellan de båda områdena.






\section{OTRYGGHET OCH UTSATTHET FÖR BROTT BLAND UNGA - EN KUNSKAPSÖVERSIKT}

Otrygghet och oro att utsättas för brott har i forskningen ofta förklarats utifrån ett individuellt perspektiv (se t.ex. LaGrange \& Ferraro, 1989 eller Warr, 1984), alltså att individuella egenskaper och erfarenheter förklarar varför vissa individer är mer otrygga än andra. Men skillnader i trygghetsupplevelse har också förklarats utifrån kontextuella faktorer. Det innebär att olika karakteristika i den omgivande miljön, till exempel bostadsområdet, påverkar i vilken utsträckning de som bor eller vistas där känner sig trygga eller otrygga. I forskningen lyfts den lokala problemnivån i form av sociala och fysiska ordningsstörningar fram som viktiga faktorer för att förstå variationer i otrygghet (Skogan \& Maxfield, 1981; Lewis \& Salem, 1986). Även vad som brukar kallas områdets eller platsens kollektiva styrka anses vara en viktig faktor för att förstå varför vissa områden eller platser upplevs som trygga eller otrygga (Sampson, 2012; Brunton-Smith, m.fl., 2014; Swatt m.fl. 2013). Kollektiv styrka kan förstås som en social process som bygger på i vilken utsträckning det bland de boende i ett specifikt område finns gemensamma normer samt vilken förmåga de har att upprätthålla dessa normer. Det är kontexten, eller den omgivande miljön, och hur denna påverkar trygghetsupplevelsen som är i fokus i den här rapporten. Det är dock viktigt att komma ihåg att det finns ett samspel mellan individ och kontext - individer påverkas på olika sätt av den omgivande miljön beroende på individuella egenskaper och vilka erfarenheter de har. 
Barns och ungdomars rörelsemönster skiljer sig från vuxnas, de använder sig av det offentliga rummet på ett annat sätt, och forskning visar att de ofta tillbringar mer tid utomhus i bostadsområdet (Leventhal m.fl., 2009). Därför är det sannolikt att barns och ungdomars uppfattningar av vad i bostadsområdet som påverkar deras trygghetsupplevelse skiljer sig från vuxnas uppfattningar (se te.x. Spilsbury m.fl., 2012). Bostadsområdet som analysenhet har länge varit av intresse inom forskningen därför att det är en kontext som ansetts ha betydande inverkan på de som bor och vistas där och därför också antas vara en viktig utgångspunkt för att förbättra barns och ungdomars livsvillkor och hälsa. Under det senaste decenniet har det kommit fler indikationer på att befolkningens livsvillkor och förutsättningar skiljer sig åt beroende på bostadsort, det finns till exempel tydliga geografiska hälsoskillnader i befolkningen (Se t.ex. Kommission för ett socialt hållbart Malmö, 2013), och den ekonomiska och etniska segregationen i Sverige ökar (Salonen, 2012). Precis som det finns tydliga skillnader mellan olika områden avseende befolkningens hälsa och socioekonomi så varierar den upplevda otryggheten mellan olika delar av staden (se t.ex. Ivert, Mellgren \& Torstensson Levander, 2015). Därför kan bostadsområdet, utöver individuella egenskaper, antas vara en viktig arena både för att förstå variationer i otrygghet och som utgångspunkt för det trygghetsskapande arbetet.

\section{Otrygghet bland ungdomar - betydelsen av området}

Precis som med trygghetsforskningen generellt fokuserar i de allra flesta fall forskning om otrygghet i bostadsområdet på vuxnas erfarenheter, upplevelser och föreställningar om vilka platser som är otrygga och vilka fenomen som upplevs som hotfulla. Det är ovanligt med studier som utgår från barns och ungdomars perspektiv. Cops (2013) menar att när ungdomar förekommer i studier av otrygghet eller oro att utsättas för brott är det ofta som indikation på ordningsstörningar, och ett fenomen som skulle kunna bidra till otrygghet i andra delar av befolkningen. Till exempel är det mer eller mindre standard att använda sig av fenomenet "ungdomar i grupp på offentlig plats som bråkar och stör" som en del av ett mått på sociala ordningsstörningar som förväntas påverka trygghetsupplevelsen. 
Det finns som sagt få större studier som fokuserar specifikt på ungdomars upplevelser av otrygghet, men enstaka frågor om otrygghet återfinns ofta i undersökningar om till exempel ungdomars levnadsvanor. Region Skånes Folkhälsorapport Barn och unga i Skåne som vänder sig till elever i årskurs sex, nio och år två på gymnasiet innehåller en fråga om eleverna känner sig trygga på olika $\operatorname{platser}^{2}$ (Fridh m.fl., 2016). Den senaste undersökningen från 2016 visar att det sedan föregående mätning (2012) skett en generell ökning av otrygghet bland flickor i alla åldrar och bland de yngre pojkarna. Att otryggheten ökat under de senaste åren är något som uppmärksammats även bland vuxna. Nationella trygghetsundersökningen (NTU) som årligen genomförs av Brottsförebyggande rådet (Brå) visar att otryggheten efter att ha legat stabilt sedan ett antal år tillbaka ökat i de senaste årens mätningar (Brå, 2018).

Generellt sett känner sig pojkar oftare trygga än vad flickor gör och skillnaden är tydligast när det gäller platser som kan definieras som offentliga -utomhus i bostadsområdet på kvällen, ute på stan/på allmänplats, i kollektivtrafiken och när de besöker konserter, festivaler eller likande (Fridh m.fl., 2016). Likande resultat, att pojkar i högre utsträckning än flickor känner sig trygga i det offentliga rummet, visar resultaten från undersökningen Ung livsstil både i Malmö (Blomdahl m.fl., 2017) och Stockholm (Blomdahl \& Elofsson, 2017). I dessa rapporter gör författarna även en analys av sambandet mellan upplevd otrygghet och psykisk hälsa. Resultaten visar att både i Stockholm och i Malmö är psykiska besvär vanligare bland de ungdomar som uppger att de ofta känner sig otrygga i kollektivtrafiken eller när de befinner sig i de centrala delarna av stan på kvällstid (Blomdahl \& Elofsson, 2017; Blomdahl m.fl., 2017).

Stockholmsenkäten som riktar sig till ungdomar i årskurs nio i grundskolan och årskurs två i gymnasiet i Stockholms kommun innehåller även den frågor rörande trygghet där en fråga mäter hur trygg personer känner sig när de går ensamma ute sent en kväll i området (Robertsson m.fl., 2017). Skillnaderna mellan åren 2010-2016 då frågan funnits med i enkäten är små, men bekräftar resultaten ovan gällande skillnader mellan pojkar och flickor. I den senaste undersök-

2 De platser som efterfrågas i enkäten är hemmet, utomhus i bostadsområdet, utomhus i bostadsområdet kvällstid, ute på stan/allmän plats och på buss/tåg. 
ningen uppgav 84 procent av pojkarna i årskurs nio att de kände sig trygga i sitt bostadsområde på kvällen, motsvarande siffra för flickorna i årskurs nio var 61 procent. I årskurs två i gymnasiet uppger 89 procent av pojkarna och 67 procent av flickorna att de känner sig trygga i bostadsområdet på kvällen (vilken är en viss ökning från föregående mätning för både flickor och pojkar). Skillnaderna är dock stora mellan olika områden inom Stockholm. De lägsta nivåerna av trygghet rapporterar flickorna i Skärholmen (41\%) och de högsta nivåerna av trygghet rapporterar pojkarna på i årskurs nio på Östermalm (94\%) och i årskurs 2 på Norrmalm (97\%) (a.a.). Resultaten från Stockholmsenkäten indikerar också att det finns en tendens till att det är färre som känner sig trygga i områden där problemnivån upplevs vara hög och den formella sociala kontrollen upplevs vara låg. Detta samband mellan ordningsstörningar och otrygghet återfinns också i den internationella litteraturen (Cops, 2010; Cops 2013). Ungdomar som upplever att deras bostadsområden har en hög nivå av ordningsstörningar oroar sig i högre utsträckning för att utsättas för brott.

\section{Strategier och undvikanden}

Tidigare forskning baserad på undersökningar bland vuxna visar att rädsla för brott kan medföra att individer vidtar vissa försiktighetsåtgärder såsom att låsa dörrar eller installera larm, och i vissa fall att individen anpassar och begränsar sin vardag (Heber, 2007; Litzen, 2006; Mellgren, 2011). Det är sannolikt att även barn och ungdomar använder sig av olika strategier för att öka sin egen trygghet, och/ eller att föräldrar på grund av oro begränsar sina barns aktiviteter på olika sätt (se tex Heber 2009). Brå undersöker regelbundet brott bland ungdomar i årskurs nio, och frågar då samtidigt om ungdomarnas oro för att utsättas för brott får konsekvenser i form av att de undvikit aktiviteter eller personer, eller att de på något annat sätt ändrat sitt beteende. Generellt sett är det vanligare att flickor ändrat eller anpassat sitt beteende på grund av oro att utsättas för brott än att pojkar gjort det (Brå, 2016). Brås senaste skolundersökning (a.a.) visar att den vanligaste undvikandestrategin bland både flickor och pojkar var att undvika vissa personer och platser. Exempelvis så angav knappt 30 procent av pojkarna att de undvikit vissa personer under det senaste året, medan motsvarande siffra för flickor var drygt 
40 procent. Resultaten från Brås skolundersökning visar också att de som utsatts för brott under de senaste 12 månaderna i större utsträckning vidtar undvikandestrategier som en konsekvens av oro att utsättas för (ytterligare) brott (a.a.). Likande mönster återfinns bland vuxna, i Nationella trygghetsundersökningen (NTU) uppgav $35 \%$ att de valt en annan väg eller färdsätt på grund av oro för brott, och även bland vuxna påverkar otrygghet kvinnors beteende i större utsträckning än mäns (Brå, 2018).

I studier som utifrån ett folkhälsoperspektiv undersöker barns och ungdomars mobilitet finns det ibland resultat kopplade till ungdomars erfarenhet av sina områden och om upplevelser av otrygghet och/eller oro för brott som kan antas begränsa deras mobilitet. En studie av vilka faktorer som påverkade ungdomars mobilitet visade att upplevd otrygghet $\mathrm{i}$ bostadsområdet påverkade på vilket sätt ungdomarna tog sig till och från skolan, detta var särskilt tydligt bland flickorna (Johansson m.fl., 2009). Flickorna använde sig i större utsträckning av strategier såsom att be om skjuts eller andra riskminimerande strategier. För flickor var det särskilt mörker som påverkade känslan av otrygghet på offentlig plats.

Det är möjligt att föräldrars inställning till i vilken utsträckning deras barn får röra sig självständigt i bostadsområdet kan påverka barnens nivåer av oro. Det finns studier som visat att föräldrar i högre utsträckning oroar sig för att deras döttrar ska utsättas för brott än för att deras söner ska drabbas (Drakulich, 2015), men kunskapen om hur detta påverkar ungdomarnas egen oro, risktagande och mobilitet är begränsad. Det finns däremot en hel del studier som visar på att föräldrars uppfattning om risk och inställningar till hur farligt ett område är påverkar i vilken utsträckning deras barn får röra sig fritt ute (Carver m.fl., 2008; Foster m.fl, 2014). Resultaten kan vara viktiga om vi antar, såsom exempelvis Cops' (2013) studie visar, att ungdomars otrygghet och oro för brott minskar ju mer de vistas ute i det offentliga rummet utan vuxet sällskap.

Riskminimerande strategier kan vara en skyddsfaktor och ett visst mått av oro kan både anses "naturligt" och ofrånkomligt i ett samhälle. Som Hale (1996) påpekar är det helt rimligt att vidta vissa 
försiktighetsåtgärder för att undvika utsatthet, men strategierna riskerar samtidigt att öka otryggheten och kan leda till isolation och en ökad känsla av utsatthet.

\section{Ungdomar och utsatthet för brott}

Att utsättas för brott kan leda till ökad oro, och det är därför viktigt att också säga något om utsatthet för brott bland ungdomar. Forskning pekar på att såväl tidigare erfarenheter av utsatthet som egenskaper i bostadsområdet påverkar ungdomars trygghet. Brottsofferundersökningar visar ett tydligt samband mellan ålder och utsatthet. I Brås senaste skolundersökning (Brå, 2016) uppgav drygt 47 procent av eleverna $\mathrm{i}$ årskurs nio att de utsatts för något av de brott som efterfrågas i undersökningen ${ }^{3}$ under de senaste tolv månaderna (detta kan jämföras med drygt 13 procent bland de vuxna i NTU ${ }^{4}$ (Brå, 2017)). Att ungdomar är mer utsatta för brott än vad vuxna är framkommer också internationellt. I England är den generella trenden att unga personer mellan åldrarna 16 och 24 år är den mest brottsutsatta gruppen vad gäller både våldsbrott och egendomsbrott (Green, 2007). Ungdomars högre utsatthet återspeglas i såväl brittiska som amerikanska brottsofferundersökningar (se t.ex. Truman \& Morgan, 2016 och Office for National Statistics, 2017). Det är svårt att göra jämförelser mellan länder eftersom resultaten presenteras på olika sätt, metodiken skiljer sig åt avseende till exempel urval, typ av frågor och definitioner, och kontexten och hur acceptabla olika beteenden är i ett samhälle. Jämförelser vad gäller sexuellt våld brukar tas upp som exempel på den sistnämnda svårigheten (Van Dijk m.fl., 2007). Med detta i åtanke verkar det trots allt vara så att ungdomars höga nivåer av utsatthet i jämförelse med den vuxna populationen är ett mönster som kan ses inte bara i Sverige utan även i andra västländer. Precis som när det gäller andra grupper i samhället finns ingen konsensus avseende om egen utsatthet verkligen leder till ökad otrygghet. I en del studier tyder resultaten på att både flickors och pojkars trygghetsupplevelse påverkas av deras erfarenheter av utsatthet, de som varit utsatta för brott rapporterar högre nivåer av otrygghet (Schreck och Miller, 2003), samtidigt finns det studier vars resultat

3 De efterfrågade brottstyperna i skolundersökningen (2016) är misshandel, hot, sexualbrott, rån och stöld. Detta är att jämföra med Nationella trygghetsundersökningen (Brå, 2017) där den avsedda utsattheten gäller brottstyperna misshandel, hot, sexualbrott, personrån, bedrägeri eller trakasserier (brott mot enskild person).

4 Brottstyperna som efterfrågas är liknande i de båda undersökningarna. 
visar att det endast verkar vara pojkarnas trygghetsupplevelse som påverkas av utsatthet (De Groof, 2008). Det finns också studier som visar att brottstypen är avgörande för huruvida egna erfarenheter av utsatthet påverkar trygghetsupplevelsen -utsatthet för personbrott var förknippat med högre nivåer av otrygghet, men motsvarande mönster fanns inte egendomsbrott (Cops, 2010). Det finns också studier som inte hittar något samband alls mellan utsatthet och otrygghet (May, 2001).

Brås skolundersökning om brott visar att det är ungefär lika många tjejer som killar som utsatts för något brott under det senaste året (Brå, 2016). Även om stöld är det brott som både tjejer och killar i störst utsträckning utsätts för visar Brås undersökning att det finns tydliga könsskillnader avseende andra brottstyper. Killar rapporterar i högre utsträckning än tjejer att de utsatts för misshandel och rån under det senaste året, och tjejer rapporterar i högre utsträckning att de utsatts för hot och sexualbrott. De könsskillnader i utsatthet för olika brottstyper som framkommer i Brås skolundersökning stämmer relativt väl överens med resultaten från till exempel Region Skånes folkhälsoenkät barn och unga (Fridh m.fl., 2016) och Stockholmsenkäten (Robertsson m.fl., 2017). Även om frågorna skiljer sig åt så är den generella bilden den samma med att killar i högre utsträckning utsätts för misshandel och tjejer oftare utsätts för sexualbrott.

Enligt Brås undersökning är det är relativt vanligt att ungdomar utsätts för brott i skolmiljön, detta gäller särskilt misshandel, hot och sexuella ofredanden. Det verkar dock som om skolmiljön är en särskilt riskfylld miljö för killar. När det gäller tjejer är till exempel inte skolan den plats där de utsatts för sexuella ofredanden, utan de anger istället ofta det hände på "någon annan, ospecificerad plats". Rån eller sexuellt tvång är brott som varken killar eller tjejer utsätts för i skolmiljön utan detta sker på andra platser (Brå, 2016).

Utöver att det finns skillnader i utsatthet mellan tjejer och killar visar Brås skolundersökning att det också finns skillnader mellan olika socioekonomiska grupper (Brå, 2016). De elever som är födda i ett annat land än Sverige, eller vars föräldrar är utlandsfödda, rapporterar i högre utsträckning än elever med svensk bakgrund att 
de blivit utsatta för brott. Det här gäller samtliga de efterfrågade brottstyperna med undantag för sexualbrott. Utsattheten tenderar även att vara högre bland de elever vars föräldrar är separerade och bland de som bor i lägenhet. Generellt sett är utsattheten lägre bland de elever vars föräldrar har en universitets- eller högskoleutbildning, har föräldrar som förvärvsarbetar och vars familjer har mer ekonomiska resurser.

En sammanställning av Brås Skolundersökning om brott i årskurs nio mellan åren 1995-2011 (Brå, 2013) visar att andelen som uppger att de utsatts för våld respektive hot i princip är konstant över tid. Den senaste skolundersökningen (2016) visar att trenden höll i sig fram tills helt nyligen (2014-2015) då andelen utsatta ökade. Andra likande undersökningar (CAN, 2015; Robertsson m.fl, 2017) visade dock inte på motsvarande ökning vilket innebär att detta resultat bör tolkas med försiktighet, särskilt eftersom frågan och strukturen på enkäten förändrats något inför den senaste undersökningen (Brå, 2016). Region Skånes folkhälsoenkät barn och unga visar att sedan 2012 har andelen som utsatts för oönskade sexuella handlingar och allvarligt hot ökat i alla åldersgrupper, samtidigt som andelen som uppger att de utsatts för lindrig misshandel har minskat (Fridh m.fl., 2016). Var tionde flicka och var tjugonde pojke uppgav att de utsatts för önskade sexuella handlingar i undersökningen från 2016, vilket är dubbelt så många jämfört med 2012.

Region Skånes folkhälsoenkät barn och unga visar att utsatthet för brott tycks öka med stigande ålder i relation till de flesta efterfrågade brottstyperna med undantag för lindrigare misshandel där utsattheten minskar med åldern (Fridh m.fl., 2016). Vidare visar undersökningen att mycket få brott anmäls till polisen med stöld och rån som undantag.

Sammanfattningsvis så tyder den relativt begränsade forskningen om ungdomars otrygghet och oro att utsättas för brott på att egenskaper i bostadsområdet och hur ungdomarna använder sig av det offentliga rummet har betydelse för deras trygghetsupplevelse. Precis som bland vuxna finns det könsskillnader i när det gäller otrygghet bland ungdomar, flickor tenderar att rapportera högre nivåer av otrygghet än 
pojkar. Även om det inte är självklart att egna erfarenheter av utsatthet för brott leder till högre nivåer av otrygghet så är det viktigt att ha i åtanke att ungdomar som grupp har en hög nivå av brottsutsatthet. 


\section{METOD}

De bostadsområden som intervjuerna med ungdomarna i den här studien kretsar kring är två bostadsområden i Malmö, Rosengård och Sofielund. Även om båda områdena har haft problem med otrygghet och kriminalitet under flera år, är det två områden som är mycket olika.

Rosengård är ett område i östra Malmö som karaktäriseras av företrädesvis flervåningshus byggda under miljonprogramsåren (främst hyresrätter men även en del bostadsrättsområden) samt ett villaområde beläget i områdets södra delar. I området finns ett par stora grönområden, cykelvägar, och mitt i Rosengård finns ett stort köpcentrum. Området delas av en stor, tätt trafikerad väg som löper tvärs igenom området. Delar av Rosengård är mycket tättbefolkat och med en ung befolkning - år 2013 var ca 30 procent under 18 år (Malmö stad, 2017), att jämföra med hela Malmö där knappt 20 procent var under 18 år samma år (Malmö stad, 2017). Sofielund är beläget i centrala Malmö och karakteriseras av en typ av blandad bebyggelse som är unik för innerstadsområden -här finns förutom flervåningshus (hyresrätter och bostadsrätter) flera kvarter bestående av småhus med egna trädgårdar. Sofielund delas upp i norra och södra och delas av en större, väl trafikerad väg. År 2013 var ca 20 procent av befolkningen under 18 år (Malmö stad, 2017) vilket ligger $\mathrm{i}$ linje med resten av Malmö. Norra Sofielund hade en lite lägre andel befolkning under 18 år än de södra delarna.

Som nämndes i inledningen kategoriseras delar av Rosengård (söder om Amiralsgatan) och Sofielund (Södra Sofielund, Seved) som sär- 
skilt utsatta områden av Polismyndighetens Nationella operativa avdelning (NOA) (Polisen, 2017). Ett särskilt utsatt område är enligt polisen ett område som "kännetecknas av en social problematik och kriminell närvaro som lett till en utbredd obenägenhet att delta $\mathrm{i}$ rättsprocessen och svårigheter för polisen att fullgöra sitt uppdrag.” (Polisen 2017, s. 10). I de här områdena menar polisen att det också i viss mån finns parallella samhällsstrukturer och extremism och en hög koncentration av kriminella.

Södra Sofielund och delar av Rosengård har under flera år varit föremål för satsningar för att komma åt de lokala problemen. De har bland annat varit en del av regeringens satsning på urbant utvecklingsarbete (URBAN 15) och av Malmö stads områdesprogram som bland annat syftat till att skapa trygga och attraktiva bostadsområden.

\section{Datainsamling}

Intervjuerna har genomförts i form av fokusgruppsintervjuer och ett par enskilda intervjuer. Utgångspunkten för intervjuerna är specifika platser som deltagarna upplever som trygga eller otrygga. Intervjuerna har utgått från den geografiska platsen för att sedan fortsätta med andra teman, såsom oro för att utsättas för brott, upplevelser av sammanhållning och social gemenskap och möjliga åtgärder för att öka tryggheten på offentlig plats. Intervjuerna har även behandlat frågor som är relaterade till polisens roll, huruvida fler poliser ökar tryggheten och förtroendet för polisen.

Intervjuerna har genomförts med endast begränsad struktur kring teman och med så öppna frågor som möjligt. Känsliga frågor om utsatthet för brott har inte berörts direkt, men det har varit föremål för diskussion i de fall en eller flera deltagare själva valt att ta upp erfarenheter av utsatthet. För en diskussion om hur detta har hanterats se Etiska överväganden längre fram i rapporten.

Det bör beaktas att formen för materialinsamling - fokusgrupper riskerar att utelämna enskilda berättelser och erfarenheter och kan därför underskatta enskilda individers oro. Det kan samtidigt finnas fördelar med fokusgruppsintervjuer genom att - förutsatt att fokusgruppen är bra sammansatt och deltagarna känner sig bekväma - de 
i större utsträckning liknar en vardaglig och naturlig miljö av social interaktion, vilket kan innebära att information kommer fram som inte hade gjort det vid en enskild intervju där formen kan bli mer "styltig" (Bryman, 2011; Liamputtong, 2011). I fokusgrupper kan deltagarna stöta på ifrågasättanden och därigenom tvingas värdera sina erfarenheter och åsikter, vilket i sin tur kan leda till ytterligare information och kunskap om motsättningar och motsägelser både mellan deltagare och inom varje enskild deltagare (Finch \& Lewis, 2003; Bryman, 2011).

\section{Urvalsförfarande}

Ungdomarna har rekryterats på olika sätt i de båda områdena. I Sofielund kontaktades högstadieskolor och rekryteringen av urvalet gjordes därifrån. Det innebär att åldern på deltagarna är 14 till 15 år och de har en gemensam nämnare i att de går i skolorna i Sofielund. Det betyder också att de inte nödvändigtvis bor där, men att de spenderar en stor del av sin tid i området.

I Rosengård har respondenterna i stället rekryterats via nyckelpersoner i föreningslivet och på fritidsgårdar. Det innebär att det är en större åldersspridning bland deltagarna i Rosengård, mellan 14 och 22 år, vilket kan ha betydelse för hur de rör sig i området och således hur de upplever området. Detta sätt att rekrytera deltagare kan innebära att urvalet blir skevt i den bemärkelsen att deltagarna, genom att de är aktiva i olika föreningar och fritidsgårdar, rör sig mycket i området och har ett nätverk där vilket i sin tur kan innebära att de är mer trygga på offentlig plats. Fördelen att rekrytera via skolor är möjligheten att nå personer som annars eventuellt inte rör sig ute i området och/eller inte aktivt söker sig till föreningslivet. Precis som med de intervjuer som gjordes i Sofielund är det inte alla deltagare i Rosengårdsintervjuerna som bor i området, även om en majoritet gör det. De som inte bor i området vistas frekvent i området, antingen genom att de går i skolan i områdena eller genom att de deltar i olika aktiviteter och/eller har ett socialt nätverk där.

Att sättet som deltagarna rekryterats skiljer sig åt mellan de olika områdena har betydelse för resultatet i respektive område, och påverkar de jämförelser som kan göras mellan de båda områdena. 
Totalt intervjuades 45 ungdomar, 26 tjejer och 19 killar.

\section{Databehandling och analytisk ansats}

Materialet har transkriberats och bearbetas i det kvalitativa databehandlingsprogrammet Nvivo för att sedan sammanställas genom användandet av en tematisk ansats. Som i flertalet kvalitativa analysansatser ligger fokus på att identifiera teman och underteman utifrån intervjumaterialet (Bryman, 2011). Ansatsen är abduktiv vilket betyder att vissa huvudteman är på förhand givna utifrån den teoretiska ansatsen och frågeschemats konstruktion. Utifrån dessa teman identifieras sedan underteman som är framträdande i materialet, men även avvikande teman har lyfts fram för att undersöka motsägelser i materialet. Materialet har behandlats och presentas i huvudsak deskriptivt och tonvikten ligger på vad (erfarenheter, känslor, åsikter och händelser) som sägs, snarare än hur det sägs. Då analysen delvis är teoridriven försöker den även svara på frågor som varför och hur i de teman som lyfts fram (Finch \& Lewis, 2003).

Materialet består som redan beskrivits till stor det av fokusgrupper och det är därför rikt på diskussioner och motsägelser, men där finns övergripande mönster. Det är också viktigt att ha i åtanke att en stor del av materialet består av så kallade "kollektiva historier" och gruppnarrativ snarare än enskilda berättelser (Tiby, 2009; Bryman, 2011).

Mer specifikt så har det transkriberade materialet kodats systematiskt för att sedan sammanställas, jämföras och presenteras. Kodningen gjordes i ett första steg genom deduktion med utgångspunkt $i$ frågeguiden och den teoretiska ansatsen. Materialet reducerades till övergripande teman som bildade ett kodnätverk (matris) som kan jämföras mellan de olika intervjuerna. Därefter gjordes en induktiv kodning, vilket betyder att kodsystemet växer, där syftet är att hitta variationer och nyanser i materialet. Den sista delen i kodningen utgörs således inte av enstaka ord och teman utan ger längre beskrivningar av kodens innehåll.

Därefter kodas ämnesinnehållet som exempelvis relationen till platser, fenomen eller personer. I nästa steg bearbetas dessa koder ytterligare 
i syfte att undersöka nyanser i materialet och motsägelsefulla berättelser kring teman i materialet som i sin tur genererar nya koder och möjliga teoretiska ansatser. Det kan resultera i längre koder såsom "det händer överallt, inte bara i Rosengård" eller "man skjuter inte och rånar inte i sitt eget område".

Nästa steg är det analytiska arbetet som går ut på att undersöka vad det reducerade materialet "egentligen" berättar (Tiby, 2009). Den analytiska fasen innebär ytterligare en tolkning av materialet som dels handlar om att finna mönster som kan representera materialet och om att jämföra de deducerade koderna, men även om att analysera den induktiva kodningen som kan ge ytterligare kunskap bortom de övergripande trenderna. Syftet med analysen är i det här fallet inte att i kvantitativa termer "mäta" ungdomarnas nivåer av oro eller att generera en representativ bild av ungdomarnas erfarenheter och orosnivåer i de båda områdena utan att lyfta fram och analysera ungdomarnas berättelser, erfarenheter och känslor i dess komplexitet, vilket gör att en sådan här analytisk ansats användbar.

\section{Begrepp och operationalisering}

Rapporten utgår från deltagarnas egna subjektiva upplevelser av sin närmiljö, och de tillfrågas om begreppen risk, oro och otrygghet. Begreppen konceptualiseras utifrån Ferraro och LaGranges (1987) distinktion mellan kognition och affektion som ofta används i forskning om rädsla för brott. Syftet är att göra en distinktion mellan uppfattningar om risker att utsättas för brott (kognition) och reaktioner på rädsla (affektion). Avgränsningen är viktig därför att individers enskilda bedömningar om risker för utsatthet inte nödvändigtvis sammanfaller med upplevelser av oro och rädsla för brott. Det är en omöjlighet att göra en operationalisering som utan frågetecken avgränsar de olika kategorierna, och tidvis sammanfaller de. Sacco \& Nakhaies (2001) metodologiska kritik - att åsikter om problemnivå, brottslighet eller andra uppfattade problem inte nödvändigtvis kan kategoriseras som ett uttryck för oro - är viktig att ha i åtanke. 


\section{Etiska överväganden}

Som nämnts tidigare är forskning som specifikt fokuserar på ungdomars trygghetsupplevelse och hur denna påverkas av deras upplevelser av bostadsområden och andra offentliga miljöer relativt begränsad. Vår intention med den här studien har varit att tillvarata och lyfta fram erfarenheter och åsikter som sällan representeras. Eftersom studien genomförts i två områden som sedan tidigare identifierats som "problemområden", och detta är något som ungdomarna vi intervjuat är mycket medvetna om, har det varit viktigt att försöka lyfta ungdomarnas erfarenheter av området utan att låta det de säger färgas för mycket av bilden av området. Vi blev också ifrågasatta av några av ungdomarna om varför vi kom just till deras områden, och en del diskussioner uppstod om varför vi valt just dessa två områden.

Även om den här studien inte handlar om egna erfarenheter av utsatthet för brott så kan samtal om ämnet otrygghet och oro att utsättas för brott lätt leda in på frågor om utsatthet, och det finns en risk att ungdomarna påminns om negativa erfarenheter. Detta behöver inte per automatik medföra negativa konsekvenser; tvärtom kan det vara positivt att få berätta om händelser och uppleva att någon lyssnar.

Projektet är godkänt av regionala etikprövningsnämnden i Lund (Dnr 2015/620). 


\section{RESULTAT}

Resultatdelen inleds med den allmänna diskussion om trygghet som förts med ungdomarna både i Rosengård och Sofielund. Sedan följer ett avsnitt om "områdeskunskap" och mobilitet. Därefter beskrivs de problem som ungdomarna i respektive område identifierat, samt de likheter och skillnader som finns mellan de båda områdena. Resultatdelen avslutas med ett längre avsnitt om otrygghet i relation till platser och fenomen som är framträdande i materialet. I citaten anges deltagarna som intervjuperson (IP) 1, 2, 3 och så vidare. Siffrorna markerar olika deltagare i den aktuella fokusgruppen som citeras, vilket betyder att IP1 i ett citat inte behöver vara samma IP1 i nästa citat. Det är således inte regelrätta alias.

\section{Trygghet som definition}

Trygghet är ett komplext begrepp och inte helt enkelt att mäta på ett pålitligt sätt (för mer diskussion kring detta se avsnittet om operationalisering ovan). För att det fortsatta samtalet skulle ha en gemensam utgångspunkt ombads ungdomarna inledningsvis försöka definiera vad trygghet var för dem. Sammantaget så är trygghet för de allra flesta av ungdomarna en känsla av att känna sig bekväm i ett sammanhang, att vara bekant med sin omgivning och sin närmiljö och att kunna gå ut utan att vara rädd för att något ska hända. Ett fåtal nämner specifika hot mot tryggheten såsom mobbing, mörker, våldtäkt och allmänt "läskiga människor".

Den generella, mindre platsbundna otryggheten karaktäriserar materialet i stort och överlag uttrycker deltagarna - med vissa undantag - att de är trygga i sina närområden. De flesta har bott och/eller spen- 
derat en stor del av sin uppväxt i Sofielund respektive Rosengård, vilket gör att de flesta har god kunskap om närområdet. En framträdande tendens i materialet är även att deltagarna ofta kan peka på olika problem i områdena när det efterfrågas som just problem. När frågan istället ställdes om vad de oroade sig för i närområdet så blev svaren färre och mindre specifika, vilket indikerar att de problem som ungdomarna identifierar inte nödvändigtvis ger upphov till känslor av otrygghet. Det är i sig inte konstigt, eftersom upplevda problem eller riskmedvetenhet inte behöver innebära oro för samma problem. Det har funnits en tendens i tidig otrygghetsforskning att mäta trygghet på ett sådant sätt så att det överlappar med upplevda problem och åsikter om brottslighet (Sacco \& Nakhaie, 2001).

För många av ungdomarna - särskilt de som intervjuades i Rosengård - är kunskapen om området och att känslan av att "alla känner alla" en viktig aspekt av trygghet. Överlag så finns det stor kunskap hos ungdomarna om sina närområden, både i Rosengård och Sofielund.

\section{Ungdomars användning av och kunskap om sina områden}

De flesta ungdomar i den här studien är som sagt överlag trygga i sina närområden, och det är något de ofta påpekar under samtalen. I intervjuerna uppkommer det ofta diskussioner kring medias och vuxnas bild av respektive område. En bild som ungdomarna i flera fall vänder sig mot, därför att de menar att de har mycket bättre kunskap om sina områden än både media och i vissa fall vuxna runt omkring dem. I vissa samtal finns ett motstånd mot att prata om sitt område, och en del av ungdomarna ifrågasatte studiens syfte. En bit in i samtalen tenderar motståndet att avta allteftersom relationen mellan intervjuare och deltagare utvecklas. Lite längre in $\mathrm{i}$ intervjuerna, när samtalen handlar om undvikande beteende så tycks det lättare för en del av deltagarna att resonera och formulera sig kring sina närområdens karaktär och vad som känns mer eller mindre otryggt. Att undvika saker och att ha säkerhetsstrategier - medvetna eller omedvetna - är en indikation på oro eftersom det påverkar och förändrar individers beteenden (Hale, 1996). Samtidigt kan vissa strategier troligtvis bidra till en ökad trygghet och känsla av kontroll, lite beroende på vilka strategier som används och hur ofta (Carvalho \& Lewis, 2003). 
Flera av deltagarna spenderar mycket tid på offentliga och semioffentliga platser i området, men det finns också en medvetenhet kring vilka platser, fenomen eller personer bör undvikas. En del av ungdomarna, både i Sofielund och i Rosengård (övervägande tjejer), säger att de inte får eller att föräldrarna inte vill att de är ute efter mörkrets inbrott.

Trots att en del av flickorna undviker att gå ut efter att det blivit mörkt så formulerar de ändå ofta sina trygghetsupplevelser genom det faktum att de känner till sina områden väl och känner sig bekväma i sin omgivning - det är särskilt framträdande i Rosengård.

IP (intervjuperson): Ja (skrattar). Typ här i Rosengård så jag kan gå ut i tofflor och sånt, typ som när jag är hemma, förstår du? Men jag kan inte gå ut med det typ så i stan och så, det går inte. För där folket förstår inte, förstår du? Typ här är, om en vän ringer "kommer du?", jag kan bara gå ner i mjukis på mig och kofta. Jag kan bara gå ner direkt ja. Typ så förstår du? Så jag känner mig jättetrygg här alltså. Men det kan bero på att jag är uppvuxen här och jag känner alla. Och det är mer så du vet när man ändå har koll på vem, alltså man har koll på allt och alla, det är enklare. Än att gå ut nånstans och man vet aldrig vem man träffar på där. (Enskild intervju Rosengård, tjej 18 år)

Majoriteten av deltagarna trivs bra i sina områden och vänder sig ofta mot mediabilden av Sofielund och Rosengård som upplevs som orättvis och till viss del missvisande.

IP: Så det blir typ att man får en bild av Sofielund men sen så samtidigt... vi går här varje dag, vissa - du bor ju här också (menar en deltagare i gruppen) - så att jag menar, jag bor inte heller så långt härifrån, jag bor i [närliggande område] så det, de här ställena som man bor i och som man går till varje dag jag menar (...) Vi har varit här nio år, tio, så jag menar de här ställena har man lärt sig och man har gått med så man har sett allting som är dåligt som man säger så. Man har sett typ att "det var inte så farligt som tidningen skrev" och "det hände, men det var inte så överdrivet”. Så såna grejer tycker jag att...det får dig att vara 
läskigt när man tänker på det men sen när man väl är i stunden i Sofielund så är det inte, men det var inte så läskigt att vara här. Det är inte så läskigt att gå i skolan här, det är ju inte. Det är inte som tidningen skriver alltså det... en helt annan bild, utifrån än från de här som bor här. Om man säger så. (Fokusgrupp Sofielund, tjejer 14-15 år)

Överlag så tycks ungdomarna i Rosengård spendera mer tid ute i området än vad ungdomarna i Sofielund gör. Förklaringen tycks enkel - det finns helt enkelt lite att göra i Sofielund enligt ungdomarna. Området framstår som anonymt i deras berättelser och flertalet umgås helst inte i Sofielund utan håller sig företrädesvis till andra offentliga eller semioffentliga platser. Några av ungdomarna besöker den fritidsgård som finns, men det tycks vara betingat av vilken skola de går på.

IP: Det känns rätt dött. Alltså inte dött som att det inte finns mycket... alltså typ om man kommer här typ en lördag eller söndag och det är efter sex-sju, alltså, så typ det finns inga affärer öppna. Det är typ bara en kiosk eller nånting. Och sen så, det är ingenting mer alltså. Så det är rätt dött. Om man skulle typ liva upp det lite mer, det skulle... (Fokusgrupp Sofielund, tjejer 14-15 år)

Lite rörelse i ett område riskerar att öka otryggheten i ett område, men ungdomarna menar att de inte håller sig borta för att de är otrygga utan för att de hellre vistas på andra platser i staden som har mer att erbjuda i termer av strukturerade eller ostrukturerade aktiviteter. Att röra sig i sitt område och därigenom få kunskap om personer och platser kan vara viktigt för att öka tryggheten, något som diskuteras i en av fokusgrupperna. Det handlar om att känna igen personer och platser och därigenom göra situationerna mer förutsägbara. Dessutom vet ungdomarna då vad de ska undvika, till exempel grupperingar som vistas frekvent på samma plats.

För ungdomarna är områdena inte ett område utan flera mindre mikro-platser med olika betydelse. Områdena kan brytas ned i mindre delar, inte bara rent geografiskt utan även demografiskt och 
ekonomiskt, något som återspeglas i ungdomarnas berättelser. Ungdomarna vet mycket om områdenas olika delar och vilka människor som befinner sig vart. Det gör att det kan navigera i det offentliga rummet och förhålla sig till de problem de upplever finns där.

\section{Problembilden i Sofielund och Rosengård -en jämförelse}

Deltagarna ombads att redogöra för problem som de upplever i sin närmiljö, problem av karaktären brott eller mindre ordningsstörningar. De problem som ungdomarna identifierar i sin närmiljö är allt från stora händelser (skjutningar) till mindre fenomen såsom individer som brukar narkotika till trafikproblem och skitsnack. Vad gäller ungdomarnas vardag så handlar det i stor utsträckning om mindre saker som upplevs som ett problem, och som de hanterar på olika sätt. Hur dessa problem påverkar ungdomarna diskuteras mer ingående i sektionen ungdomars otrygghet.

I Sofielund finns enligt ungdomarna problem med öppet bruk av narkotika. Det handlar företrädesvis om få individer som använder narkotika öppet på olika plaster i Sofielund och mot Möllevångstorget och som av ungdomarna klassas som "missbrukare", äldre och synbart nedgångna. Ungdomarna beskriver även i viss utsträckning problem med killar i grupp och konflikter mellan skolorna.

Seved i Södra Sofielund är ett återkommande tema i samtalen som ger upphov till längre diskussioner som präglas av föreställningen om Seved. Ett par av deltagarna bor eller har bott på Seved och återger sina känslor inför området:

IP2: Jag bodde där innan.

Intervjuare: Hur påverkar det? tycker du?

IP1: Man... man har hört så mycket men det är mycket så här gänggrejer som håller på där. Med narkotika och så.

IP2: Alltså jag har bott där innan när jag flyttade sen till [område]. Så var det mycket så brott och till och med grannarna kunde begå brott, det var typ helt normalt. Det var... ja. Alltså det känns nästan som ett ghetto så att det... (Fokusgrupp Sofielund, tjejer 14-15 år) 
Norra Sofielund upplevs av en del informanter som öde och ganska anonymt med lite aktiviteter, vilket innebär att de inte spenderar så mycket tid i området utanför skoltid. Ungdomarna från Sofielund hade överlag svårt att nämna problem som var kopplade specifikt till närområdet, och det framkom att definitionen av det geografiska området var otydlig och skiljde sig åt mellan ungdomarna. Sofielund är ett litet område som domineras av bostäder och gränsar till mer utpräglade innerstadsområden (Möllevången) med en typisk innerstadsproblematik vad gäller exempelvis nedskräpning eller personer som är påverkade av alkohol eller narkotika. Närheten till Möllevången (dvs innerstaden) är återkommande i ungdomarnas berättelser och styrker antagandet om otrygghetens eventuella spridningseffekter (jmf. t.ex. Sampson, 2006; 2012). Det framkommer att ungdomarnas upplevelser också präglas av att det på ett litet område i norra delen av Sofielund finns två högstadieskolor. En grupp medverkande uttrycker det så här:

IP3: Möllevången är det mycket vandalism.

IP2: Fast i Sofielund jag kan känna att... eh alltså jag känner att, jag vill inte skylla nu på en viss, men jag känner att det oftast, det är ju ungdomarna som oftast förstör, om man ska säga så. För att jag känner att vid den här åldern när man är 15-16 och kanske 14 och lite äldre, att den här åldern då du känner att du kan och du har makten att säga nej, att du har makten att förstöra nånting så vill man gärna testa det. Och jag kan känna alltså, jag själv har ju eh alltså jag har ju inte gått och tatt sönder nånting eller nåt sånt men jag kan känna att du vet den här makten får man, man blir liksom triggad, man vill gärna testa det. Och jag kan känna att här, som sagt, det är väldigt mycket ungdomar så att det förekommer lite oftare, det kanske därför många tror liksom att "åh det här är bland de farligaste ställena", för att det är väldigt mycket ungdomar, för det är ju mest ungdomar som sagt, som gör såna grejer, brott som inte är för grova men det är ändå brott, alltså du vet...

IP1: Också att det finns två skolor i Sofielund, det kanske finns mer men, [skola 1] och [skola 2] det finns elever och det är i den ålder, det finns många, tjugo styckena nior är det här som går i nian, och då är det liksom, då gör man saker kanske på rasten 
för man är bara rastlös, man vill göra nånting och ehm ja, då blir det nåt, då händer nånting i Sofielund därför.

(Fokusgrupp Sofielund, tjejer 14-15 år)

Deltagarna ger här uttryck för att det finns ungdomar i närområdet och i skolmiljön som testar gränser och "förstör". Brottsförebyggande rådets återkommande skolundersökningar visar att skolmiljön är den främsta arenan för högstadieungdomars utsatthet, främst vad gäller lindrigare och grövre misshandel, hot och sexuellt ofredande (Brå, 2016).

I Rosengård pekar deltagarna delvis ut andra problem och skjutningar tar mycket plats i samtalen. Intervjuerna skedde inte långt efter mordet på en 16-årig kille på en busshållplats i Rosengård och det har påverkat flera av ungdomarna.

Intervjuare: Mm. Men upplever ni att det har blivit...mer som händer nu som händer nu senaste tiden? Eller du sa att ehm att det har blivit mer på sistone?

IP1: Alltså saken är att det har alltid varit så, men i och med att typ media har börjat uppmärksamma det mycket mer än vad de gjorde innan. Och typ så här kanske och kanske skriva om en grej i kanske fem dagar istället för två timmar, så tror jag att t.ex. bland annat min mamma reagerar mer på det. Alltså hon får för sig att det är större.

IP2: För att alla snackar om det.

IP1: Ja exakt. Men alltså det har alltid varit såsom det är. Kanske man inte har brytt sig lika mycket, alltså gå typ så här. Men sen är det ju mycket folk som alltså som jag bland annat har känt som har blivit skjutna och dött, på alltså sistone. Och det kanske också därför man tar på det lite större än vad heter det...som man gjort innan. för det börjar komma nära en helt enkelt. Hade det varit Stockholm, jag hade inte brytt mig helt ärligt. men i och med att det är typ så framför min dörr och grejer, så alltså man... ja...man reagerar såklart. (Fokusgrupp Rosengård tjejer, 18-19 år) 
Skjutningar är (av naturliga skäl?) bland de problem som nämns flest gånger i materialet men det bör inte tolkas som att det är mest frekvent förekommande problemet i Rosengård. Det tycks däremot finnas ett stort behov bland deltagarna att prata om fenomenet och detaljer de har hört om eller sett genom åren.

Även i Sofielund talas det om allvarligare brottslighet såsom skjutningar och sprängningar men då främst i relation till Södra Sofielund (Seved) eller Malmö i stort, och få verkar ha egna erfarenheter. Majoriteten av deltagarna i Sofielund bor i de norra delarna eller utanför Sofielund och tycks spendera förhållandevis lite tid i området, vilket naturligtvis också har betydelse för identifierandet av problem.

Mer platsspecifika och frekventa problem som pekas ut i Rosengård handlar om gäng, grupper av ungdomar och fenomen som är kopplade till skitsnack, tråkningar och konflikter. Narkotika är till skillnad från Sofielund inte ett tema som kommer upp i någon större utsträckning i samtalen med ungdomarna i Rosengård, men däremot finns - som svar på en specifik fråga - det en medvetenhet om att det säljs och brukas bland vissa grupper.

Ungdomarna i särskilt ett par fokusgrupper i Rosengård är väl medvetna om de olika grupperingarna och vilka personerna är som hänger på de olika platserna. Som fenomen verkar grupperingarna inte störa dem nämnvärt, utöver den gruppen som befinner sig kring Ramels väg som beskrivs som störande och med ett dåligt beteende gentemot framför allt tjejer. På de övriga platserna upplever ungdomarna att de får respekt, men riktigt varför framgår inte i intervjuerna. Ramels väg är en plats som återkommer i intervjuerna och beskrivs som ett problem och som en plats flera av ungdomarna - både killar och tjejer - undviker. Ett par av killarna som intervjuats uppger att de gärna vistas och umgås kring Ramels väg, men alla tjejer som intervjuats undviker platsen.

I intervjuerna överlag är innebörden av "gäng" inte alltid tydlig, en del tolkar det som grupperingar av ungdomar som umgås, medan andra deltagare tolkar det i termer av kriminella grupperingar. Orden "grupp" och "gäng" används på ett oprecist sätt, både av oss som 
intervjuare och av deltagarna, något som ger upphov till en diskussion i en av fokusgrupperna om vad ett gäng är. Samtalen handlar om allt från ospecificerat umgänge mellan konstellationer av ungdomar till kriminella grupperingar som rör sig på vissa platser. Flertalet ungdomar upplever grupperna eller gängen som ett problem på offentlig plats som de behöver förhålla sig till, vara medvetna om att de finns där och "bete" sig på rätt sätt. Att bete sig på rätt sätt kan vara att inte titta någon $\mathrm{i}$ ögonen för att undvika provokation, undvika grupper av killar eller särskilda platser och så vidare. Sammanfattningsvis är upplevelsen inte avhängig av vad grupperna faktiskt gör - det spelar kanske mindre roll. Grupperna med sina respektive territorier upplevs som ett problem att förhålla sig till och påverkar tryggheten, både för tjejer och killar men kanske framför allt för tjejerna i materialet. Överlag framträder i intervjuerna en bild av en offentlig miljö som i viss utsträckning formas av män och pojkar som tar mycket plats genom ostrukturerad närvaro, exempelvis genom att det upplevs att de "hänger" och "glor" utan egentligt syfte.

Detaljerna kring Rosengårds problembild är till viss del mer konkreta och mer diversifierade vilket kan bero på flera saker utöver de faktiska omständigheterna. Materialet är mer omfattande såtillvida att fokusgrupperna har varit något mindre och materialet innehåller utöver det ett par enskilda intervjuer, vilket inte är fallet för materialet i Sofielund. Rosengård är även ett mycket större område sett till både yta och befolkning, vilket kan innebära en mer varierad problembild.

Att det finns vissa olikheter i hur urvalet av deltagare gjorts i de båda områdena är viktigt att ta i beaktande vid en jämförelse. Majoriteten av deltagarna i Rosengård bor och är uppväxta i området och de spenderar mycket tid i området. Det finns dessutom en större åldersspridning där de flesta är över 15 år och har börjat gymnasiet. Det kan betyda att mer ostrukturerad tid spenderas med vänner på offentliga och semi-offentliga platser över en längre tid på dagen och kvällen. Ungdomarna i Sofielund är i åldern 14-15 år och kan antas ha en mer strukturerad vardag med en högre grad av tillsyn från både skola och vårdnadshavare. Ungdomarna i Sofielund uppger dessutom att det finns lite aktiviteter i Sofielund och att de hellre umgås på andra ställen i Malmö, vilket inte är fallet för ungdomarna i Rosen- 
gård. Skillnader i ålder är även viktig i med tanke på att några få år kan innebära stora skillnader i mental mognad och fysisk utveckling (Beazley m.fl., 2009) som (bland annat) kan vara avgörande för hur ungdomar uppfattar och tolkar sin omgivning, sina erfarenheter av och på offentlig plats samt hur mycket eller lite de vistas på offentlig plats.

\section{Ungdomars otrygghet - övergripande teman}

I samtalen kring vad otrygghet är för deltagarna och vad som skulle kunna få dem att känna sig otrygga finns det vissa mönster som framträder i intervjuerna med ungdomarna från båda områdena. I intervjuerna efterfrågades specifikt ungdomarnas relation till otrygga platser och fenomen. I avsnittet om platser nedan beskrivs de platser som ungdomarna oftast pratar om och varför just dessa platser upplevs som otrygga. Avsnittet om fenomen är indelat efter de teman som är frekvent förekommande i materialet. De fenomen som beskrivs mer ingående är narkotika, grupperingar och gäng, sexuellt våld och trakasserier och mansdominerade ytor. Vissa teman är mer generella i den bemärkelsen att de inte kopplas till ett specifikt område utan det är snarare en oro som är ständigt närvarande, exempelvis för sexuellt våld. Under samtalens gång framkommer det dock tydligare hur de ändå kan kopplas till platsspecifika erfarenheter i ungdomarnas närmiljö. Det är värt att notera att ovan nämnda teman inte nödvändigtvis kopplade till oro för att utsättas för brott utan otrygghet i en bredare bemärkelse såsom känslor av obehag och att vara obekväm.

\section{Platser}

En sammanställning av materialet visar att vissa otrygga platser återkommer i intervjuerna med ungdomarna. I Sofielund gäller det framförallt vissa gator runt Seved i Södra Sofielund, PLM-parken, Enskifteshagen och även Jesusparken och området runtomkring som ligger i Norra Sofielund. PLM-parken upplevs som otrygg därför att den uppfattas som tom och ödslig eller för att det finns vittnesmål om "skumma typer", grupper av killar och öppet narkotikabruk. 
IP3: Jag kan tycka där borta vid, vet inte om det [namn], som du sa PLM-parken där. Och Enighet. Kring där.

IP1: PLM är inte, det finns...där man går runt PLM-parken, du ser träd och sånt när det är mörkt, ja shit.

IP2: Då kommer man tillbaks till det här när det är mörkt, när det är mörkt är det en helt annan sak!

IP3: Jag tycker allt är läskigt när det är mörkt! Det blir så.

IP1: Jag har gått förbi där när det var mörkt och då var det såna gäng du vet. Ehm så hära killar som stod där på ehm på vägen du vet. Det var liksom inte så, asså, om jag visste att de hade vart där hade jag nog gått nån annan du vet, lite andra steg bortifrån. Ehm... men det är inte så farligt. De liksom de gjorde inget, men bara den här känslan att det är sånt gäng nu, det gjorde mig (...) plus att det var kväll. Men när det inte är kväll så PLM-parken, det är trevligt där.

IP2: Och sen var det inte då en gång när vi var där och vi hade idrott som han där, det var en sån man som eh tog droger eller nånting?

IP1: Jooo, det var ju, vi var små då, det var länge sen så alla blev ju jätterädda och sprang till läraren och ba "han tar droger!". IP2: Jamen så jag känner att här är, som sagt, väldigt mycket ehm... missbrukare. ja. det är, eller väldigt mycket, Jag känner att det har varit några missbrukare här som tar det väldigt offentligt och väldigt offentligt tar droger. (Fokusgrupp Sofielund, tjejer 14-15 år)

Platser i norra Sofielund är vanligt förekommande i materialet och på ett mer detaljerat sätt, antagligen för att majoriteten av deltagarna vistas där i större utsträckning då de går i skolan där.

Rasmusgatan och Jespersgatan på Seved i Södra Sofielund har flera av ungdomarna negativa upplevelser ifrån eller har hört om negativa händelser, ofta i form av gängbråk. Några av deltagarna bor i det aktuella området och de menar att de är vana vid det och inte tänker så mycket på det, medan det för de ungdomar som inte bor i området tycks ge upphov till högre nivåer av otrygghet.

IP1: Men det finns vissa områden som är alltså ändå lite farliga. Inte farlig farlig men... 
IP2: Fast inte nära skolan. Fast där jag bor det är hit och hit.

Interviuare: Vart var det du bodde?

IP2: [plats i Södra Sofielund]

Intervjuare: Vilka platser är det där du inte skulle...

IP2: Alltså Rasmusgatan, Sofiagatan. Det händer alltid mycket fast jag är van vid det så. Det är inte nåt nytt för mig. (Fokusgrupp Sofielund, blandad 14-15 år)

$/ /$

IP: Ehm jag tycker det, jag som bor här ehm... tycker att det är liksom ett fint område. Det känns ganska tryggt med tanke på att min skola är här ehm... en faktor eller vad man ska säga är Seved. Det är ju inte världens (andra hummar instämmande) safaste plats eller vad man ska säga. (Fokusgrupp Sofielund, tjejer 14-15 år)

Oron som ungdomarna känner inför delar av Södra Sofielund är i stor utsträckning kopplat till gäng som de har hört (eller erfarit) befinner sig på vissa gator. De känner obehag inför att gå där och är rädda för att hamna i vägen för kriminell verksamhet.

I Rosengård tycks oron delvis handla om andra saker, såsom grupperingar och konflikter, ryktesspridning och i viss utsträckning trakasserier av kvinnor på offentlig plats. Men även här är problemen ofta tydligt kopplade till specifika platser. Den höga närvaron av olika grupper av gäng och ungdomar/unga vuxna som "hänger" på olika platser i Rosengård påverkar ungdomarnas vardag på olika sätt. Det kan även vara yngre barn som skapar obehag och irritation hos vissa deltagare. På frågan om det finns några platser som de undviker svarar tjejerna i en fokusgrupp att de håller sig undan från Ramels väg i den mån det går.

IP3: Vid mini-livs och sånt där.

IP2: Min [släkting] bor där, jag brukar gå förbi och sånt, men...

IP2:...när de killarna sitter här, jag går förbi, men de ska alltid kommentera.

IP1: Ja. 
IP2: Jag bråkade med en kille där för nån dag sen. De ska alltid kommentera...vem du är och såna grejer. Det är såna små. De vill bara ha uppmärksamhet. Som att de leker att de är nånting. men annars, de där de, jag vet att de har alltid flippat med oss men vi har alltid bråkat med dem, men de har flippat med oss. Men det är inte så att vi....

Intervjuare: Det känns inte hotfullt menar du?

IP2: Nej.

IP1: Jag har aldrig tagit det som hot. Det är bara typ att de är riktigt smutsiga. Men de där de är jätteäckliga killar. Och tjejerna.

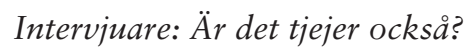

IP1: Ja. Småbarnen.

IP2: De är också i vår ålder.

Intervjuare: Vad gör småbarnen?

IP2: Igår när jag går förbi, en liten tjej kommer och drar mitt hår! (Fokusgrupp Rosengård, tjejer, 16-17 år)

Även om deltagarna uppger att de inte upplever grupperna som hotfulla så är det ändå tillräckligt för att de ska undvika platsen. Ramels väg i Herrgården är den plats som oftast nämns som en plats som undviks, både av killar och tjejer. Däremot finns det vissa av killarna i materialet som gärna spenderar tid runt Ramels väg, vilket sannolikt hänger ihop med att de är uppvuxna runt det området. Ungdomarna har olika relation till och föreställningar om olika platser och precis som Seved i Sofielund, leder Ramels väg nästan utan undantag, till diskussioner i samtalen med ungdomarna i Rosengård. Platsen är väl känd för ungdomarna och oavsett hur ungdomarna känner inför platsen så finns det en medvetenhet om de olika problem som finns där.

\section{Fenomen}

\section{Narkotika}

PLM-parken, Enskifteshagen och Jesusparken, i norra Sofielund, upplevs som otrygga av flera ungdomar främst därför att de är kopplade till öppet bruk av narkotika av vad som beskrivs som äldre personer. Det har alltså i liten utsträckning att göra med försäljning av narkotika och grupperingar, även om viss oro för grupper av killar förekommer i anslutning till PLM-parken. Här spelar troligtvis flera faktorer in, såsom rädslan för främlingar och föreställningar om per- 
soner med långt gången beroendeproblematik som instabila. Tidigare forskning visar att otryggheten kan öka om en situation upplevs som oförutsägbar, om känslan av kontroll är liten och konsekvenserna av eventuell utsatthet upplevs som stora (Jackson, 2011). Det kan delvis förklara den oro som ungdomarna känner inför vuxna personers öppna narkotikabruk, tillsammans med historier som florerade på skolan om barn och ungdomar som blivit jagade med sprutor.

Att ungdomarna i Sofielund i större utsträckning än ungdomarna i Rosengård oroar sig för narkotika och personer som använder narkotika kan ha flera förklaringar. Ungdomarna i Sofielund är yngre och upplever kanske det öppna bruket på ett annat sätt än de äldre ungdomarna i Rosengård, men det är även en indikation på att det upplevs vara ett mer frekvent problem i Sofielund än vad det är i Rosengård. Det är enbart en av ungdomarna i Rosengårdsmaterialet som nämner drogpåverkan på offentlig plats som ett problem. När frågan lyfts i en av fokusgrupperna i Rosengård så menar ungdomarna att det är väldigt ovanligt med öppet alkohol- och narkotikabruk. Det härleds snarare till city eller Värnhemstorget. Däremot vet ungdomarna om att det förekommer handel med narkotika, men det verkar inte påverka tryggheten. Däremot upplevs det som ett problem av flera ungdomar då de ser det som en potentiell väg in i kriminalitet för yngre ungdomar.

\section{Grupperingar och gäng}

De flesta av ungdomarna i Rosengård tar upp förekomsten av grupperingar och gäng på specifika platser som en källa till obehag och ibland otrygghet. Det råder ofta viss begreppsförvirring i samtalen avseende vad som egentligen menas med "killar i grupp", "grupperingar", "gäng" och så vidare, något som vissa har påtalat i samtalen. Det reflekterar kanske en allmän, samhällelig förvirring kring de olika begreppen och vad som egentligen avses. En grupp med ungdomar som hänger ostrukturerat kan uppfattas som ett problem utan att de för den sakens skull begår kriminella handlingar. Sedan finns det gäng i bemärkelsen av toppstyrda organisationer med äldre, kända, kriminella som ledare som har en så kallad svans - "springpojkar", som en tjej i materialitet uttrycker det. Dessa grupper kan säkert överlappa och en tydlig avgränsning är vansklig att göra. 
Vad som framkommer kring grupperingar och gäng och som har betydelse för ungdomarnas trygghet är att det kan uppstå konfliktsituationer mellan grupperingarna. Flera av ungdomarna nämner också att de känner sig utsatta för verbala påhopp i form av elaka kommentarer och annan ovälkommen uppmärksamhet. Värst kan det vara för tjejer som kommer utifrån och inte "hör" till området, menar vissa. Det är inte alltid klart vad de olika grupperna faktiskt gör på sina respektive platser, mer än att hänga. En av tjejerna säger helt kort att "De vill ju vakta, fattar du vad jag menar?”. Ungdomarnas tillträde och nyttjande av det offentliga rummet tycks till viss del villkoras av denna "territorialitet" (se tex. Kintrea, 2008).

Som nämndes inledningsvis är Rosengårds befolkning mycket ung och det är många ungdomar på liten yta vilket skapar uppmärksamhet bland både vuxna och ungdomar. Den utbredda trångboddheten resulterar även i att ungdomar i hög utsträckning spenderar en stor del av sin tid på offentlig plats, vilket kan bidra till ökad risk för utsatthet och konflikter men även för exponering för kriminalitet och kriminella personer (Polisen, 2017). Bland ungdomarna i Rosengård finns det en stor medvetenhet kring detta, och framför allt en stark övertygelse att utsatthet för våld enbart drabbar de som "väljer det själva” genom att umgås i fel kretsar. Denna starka övertygelse, som delas av de allra flesta ungdomar som intervjuats, kan bidra till att de känner sig trygga i sina områden. Både i Sofielund och Rosengård påpekar ungdomarna vikten av den kunskap de har om områdets karaktär och de personer som vistas på offentlig plats, som något som verkar trygghetsskapande. Den här typen av kunskap är troligtvis högre bland många av ungdomarna i dessa områden än bland de vuxna boende. En kille som bor i Herrgården säger så här:

IP: Jag kan säga så här att, vi, det finns två olika världar. Den kriminella och den normala. Vi som är här vi lever i den här normala. Den kriminella, nästan alla känner varandra där och ingenting kommer hända dig om inte du har gjort nånting. Det kan jag lova, speciellt i Rosengård. Dör de, alltså om de ska gå ut och råna nån, slå nån, misshandla eller i värsta fall skjuta nån så är de hundra procent säkra på vem det är. Och när det görs och varför det görs. Så för min del jag kan gå ut kl 1, 2, 3 på natten 
eller morgonen, det spelar ingen roll alltså, jag hade inte varit rädd för någon. För om inte, om inte du har gjort nånting, inget kommer hända dig. Däremot om du har gjort nånting, då ska du vara rädd om dig själv. (Fokusgrupp Rosengård, killar 15-22 år)

Citatet ovan exemplifierar den ganska starka övertygelsen hos flera av ungdomarna $\mathrm{i}$ både Rosengård och Sofielund om att utsatthet kommer till den som "förtjänar" det. Den främsta riskminimeringen handlar således om att i möjligaste mån undvika vissa grupper eller vissa situationer, enligt en del av ungdomarna. Det antagandet skapar troligen i sig själv trygghet och visar också på att ungdomarna har kunskap om hur de ska navigera mellan dessa båda "världar" som beskrivs ovan.

Även i Sofielund beskrivs konflikter mellan vissa grupperingar, men de beskrivs i mycket mindre detaljerade ordalag. Det tycks främst handla om konflikter mellan skolor i området som gör att vissa skolområden känns otrygga. I två av fokusgrupperna i Sofielund diskuteras behovet av fler närvarande vuxna (mentorer och/eller rastvakter) omkring skolområdet och i skolan, dels för att det generellt skulle kunna öka tryggheten men också för att snabbare kunna säga till någon om stök uppstår.

Dessa konflikter har också inneburit att fritidsgården främst besöks av ungdomar från den ena av skolorna, och undviks av eleverna från den andra. Tendensen till "territorialitet" finns således även $\mathrm{i}$ Sofielund, men på andra arenor. Bristen på aktiviteter som en del av ungdomarna uttrycker är ett problem i Sofielund och den allmänna anonymiteten i form av få kvällsöppna butiker och lite rörelse på kvällarna kan bidra till en känsla av allmän otrygghet bland både ungdomar och vuxna (Egnell \& Ivert, kommande).

I delar av Rosengård kan istället bristen på anonymitet bidra till att ungdomarna känner sig otrygga. Det kan handla om mobbning, ryktesspridning, tråkningar och också sexuella trakasserier som uttrycks i en av fokusgrupperna. 
IP: Alltså, alltså man känner sig trygg och sånt fast typ så...enda som kanske är ett problem är att typ så...alltså här i vårt område, alltså det är stort. Typ det är uppdelat. Vi har Ramels väg, Bennets väg, Rosen, alltså von Rosens väg och sånt. Och sen i varje, alltså i varje del, det, hela det är Rosengård ju, men det är fortfarande uppdelat. Typ man vet vem som...jag kan gå varje dag till typ Babylon alltså där vid Ramels väg, jag ser samma folk varje dag. Sen om jag går till Ica, jag vet redan vilka folk som kommer vara där. Så det är så klassiskt. Alltså jag vet inte, det är som typ jag...jag kan inte gå och typ, nu vid Bazaaren sina här mitt i Rosengård, typ jag inte gå dit och sätta mig där med mina vänner och så för jag vet att det kommer finnas alltså särskilt folk som är där. Alltså typ så, typ äldre killar och sånt. Och sen, det är många som snackar i Rosengård också. Alltså om man tar för sig för mycket, typ man...man syns mycket och hörs mycket, direkt alla vet. Så det är sånt.

\section{Intervjuare: Skitsnack menar du?}

IP: Ja det är mycket så...typ nu om det är nån som visar sig riktigt mycket, jag vet direkt, folk snackar om det. Att typ han här eh visar att han är nånting och så. Och det är det som är leder till att till sist många blir skjutna och såna saker. Det kan vara för rykt, alltså torra konflikter. Det kan vara såna småsaker. Ja. (Enskild intervju Rosengård, tjej 18 år)

I det här citatet berättar deltagaren om hur hon upplever Rosengårds olika offentliga rum och hur konflikter uppstår, till synes ofta grundade i helt triviala saker. Det påverkar henne i och med att hon känner till vilka som hänger var och att hon måste förhålla sig till dem för att det inte ska uppstå "skitsnack" eller för att hon inte ska hamna emellan olika mindre konflikter. Just ryktesspridning, skitsnack och mobbing, det vill säga olika former av negativ social kontroll är det flera av deltagarna som tar upp som ett problem i området. På samma gång som det är en trygghet att "alla känner alla” så kan det snabbt leda till ryktesspridning som får negativa effekter, enligt flera av deltagarna.

IP1: Alltså på Rosengård kan man helt enkelt inte vara sig själv och jag skojar inte, det är så alltså du kan inte gå runt hur du vill. 
Om...alltså om du har så höga förhoppningar på att ingen kommer döma dig och sånt, du har redan...

IP2: Man hör även kvinnor snacka skit.

IP1: Jaja det är såpass, fattar du. Man stöttar inte varandra för fem öre så...helt enkelt om man inte vill bli dömd...alltså...

IP2: Fast så är det på Möllevången också.

IP1: Ja jag menar om man vill...ja om man vill bli dömd så är typ Möllevången och Rosengård rätt ställe att komma till.

(Fokusgrupp Rosengård, tjejer 18-19 år)

\section{Sexualbrott och trakasserier}

Det är uteslutande tjejer som pratar om risken och oron för sexuellt våld och trakasserier $\mathrm{i}$ intervjuerna. Oron för grövre sexuellt våld handlar i princip enbart om ett yttre hot, det vill säga en rädsla för okända män på offentlig plats - ofta kopplat till kvällstid. Oron är inte platsspecifik såtillvida att de flesta ger uttryck för att ett överfall kan hända var som helst - oron är något som finns med tjejerna vart de än går.

När det gäller oro för sexuella trakasserier och ovälkomna kommentarer är även denna oro generell, men i intervjuerna kopplas den här typen av problem även till specifika platser. Tjejer i en fokusgrupp berättar om sexuella trakasserier och ovälkomna kommentarer i Rosengård centrums som skapar obehag och en ovilja att visats i köpcentret, främst kring de två centrala caféerna:

Intervjuare: Är det nånstans $i$ Rosengård där ni känner er mindre trygga, rent platsmässigt så?

IP1: Alltså Rosengårds centrum kanske. Eller alltså inte otrygga men det är bara äckligt. Det är fullt med män som typ så här...”ks ks” och grejer! (skrattar)

IP2: Ja de raggar jättemycket på en.

IP1: Och det är alltså 50-åriga män man ba...alltså det...

IP2: Man kan inte gå där hur man vill tex. Om man måste gå ensam. Alltid nån ska kolla.

IP1: Alltså allmänt hela Rosengård är så. Hela Rosengård är så. IP2: Egentligen nja, jo jag vet inte. Det finns vissa ställen där det... (Fokusgrupp Rosengård, tjejer 18-19 år) 
Tjejerna i den här fokusgruppen känner sig utsatta för sexuella trakasserier och kommentarer i Rosengård centrum vilket väcker obehag och gör att de helst undviker platsen om de är ensamma. Det innebär ett ingrepp i deras vardag och de skulle helst se att hela centrum rivs eller byggs om. Männen som hänvisas till är alltså inte en del av de andra grupperingarna som ungdomar förhåller sig till på offentlig plats utan beskrivs som äldre, enskilda män som tar sig friheter att kommentera tjejer som går förbi.

Denna ständiga vaksamhet beskrivs av många tjejer - och killar - i materialet, ibland kopplat till specifika platser men ofta på en mer generell basis:

IP1: Jag hörde på Zara Larssons sommarprat förra året tror jag det var. Det var, jag tror det var kopiator, vad heter det? Jaja, skit samma. Hon sa nånting i alla fall att om man går själv på en gata, så här på kvällen, och man ser en man så greppar man sina nycklar hårdare. Och det är typ sant. Ändå.

IP2: Och hon typ sa så här: "förlåt, för att jag gör det." För man känner ju inte personen. Och det liksom den kan inte rå för att det blir så, alltså att ens hjärta pumpar lite extra. Alltså när man... jag vet inte jag ska förklara det men ah... (Fokusgrupp Sofielund, tjejer 14-15 år)

Det är vanligt att rädslan beskrivs på det här sättet bland ungdomarna och det är inte alltid kopplat till en rädsla för någon specifik typ av brott, utan det handlar dels om en föreställning om män och en känsla av inte ha kontroll över situationen. En tjej berättar exempelvis att hon har pepparsprej med sig. Det första citatet rör mer specifika erfarenheter av trakasserier på en känd plats (Rosengård centrum) medan andra beskrivningarna handlar om hypotetiska platser och hypotetiska möten. Resultaten är i linje med vad andra studier visat som tar upp frågan om ungdomars oro för brott generellt, och tjejers oro för sexuellt våld specifikt. Tjejer känner sig i högre utsträckning otrygga på offentlig plats än vad killar gör (Fridh m.fl., 2016; Blomdahl m.fl., 2017; Blomdahl \& Elofsson, 2017) och de oroar sig i högre grad för sexuellt våld (Johansson m.fl., 2012). Liknande resultat återfinns i den vuxna populationen. 
Mansdominerade ytor - inte bara ett problem för tjejer

Erfarenheter av oro på offentlig plats i relation till grupperingar av män är dock inte förbehållet tjejerna i materialet utan diskussionen förekommer även bland killarna och är en del av deras vardag som de måste förhålla sig till:

IP2: Alltså typ om det är på kvällen och du går förbi en person och du kollar på han helt mycket, det är klart han kan bli arg på dig. Det är bara blanda inte in dig i nånting, bara gör ditt så händer ingenting.

IP3: Men det är också det du vet om man är, som de sa på kvällen då, och sen det är, du går förbi ett litet gäng. Det är alltid nån som ska försöka leka man bland det gänget och ska gå och jävlas med nån annan som är utanför det gänget. Det är det man är mest rädd för. Annars ingenting.

IP5: De ser det som en chans som de vill plocka liksom. De kan råna, just nu. Det är kväll, och man har huva på, du kan inte se vem de är. Vissa försöker utnyttja chansen. (Fokusgrupp Rosengård, killar 15-22 år)

Här kopplas hotet tydligare till en oro för utsatthet för våld och att göra "fel" i mötet med killar i grupp på offentlig plats, men också om känslan av obehag inför mötet med "främlingen" som man vet lite om. Citaten är tydliga i den bemärkelsen att även här "vet" ungdomarna hur de ska förhålla sig, eller rättare sagt hur de inte ska förhålla sig. Ungdomarna beskriver riskminimerande strategier och undvikanden som de använder sig av i den offentliga miljön, beteenden som att vända bort blicken, inte utmana, byta trottoarsida och ta så lite plats som möjligt för att undvika eventuella provokationer. Liknande resultat om killars oro på offentlig plats återfinns i andra kvalitativa studier (se t.ex. Johansson m.fl., 2012). Det finns ett socialt spel i mötet mellan människor på offentlig plats som är viktigt att kunna för att öka sin egen trygghet. Det är dock åter viktigt att påpeka att ytterst få i materialet uttrycker att oro över att utsättas för brott är något som påverkar deras vardag i någon högre utsträckning, men de flesta kan nämna någonting. Det bör också tas i beaktande att vissa riskminimerande strategier är så pass normaliserade så att de tas för givna och således inte ses som ett aktivt, rationellt val. 
Även killgrupperna i Sofielund hittar sätt att förhålla sig till grupper på offentlig plats som ett sätt att minimera risken för utsatthet eller att bli indragen i någonting som de inte har kontroll över.

IP: Det är väl, det handlar också vilka man umgås med i ett område. Det kanske finns ett område där det är större risk av att man kan bli skadad, men det betyder också att det finns ett umgänge, lite större där som är anledningen till det. Så om man håller sig borta, man känner själv, detta är någonting som inte riktigt stämmer med det här umgänget. Så bara håll dig lite borta från det dåliga. (Fokusgrupp Sofielund, killar 14-15 år)

Det är återigen tydligt att många av ungdomarna vet (eller anser sig veta) vart "det dåliga" finns och att de behöver göra ett aktivt, medvetet val för att undvika risken för utsatthet eller för att hamna i kriminogena situationer.

\section{"Killar mer utsatta än tjejer"}

Det finns vissa tendenser i materialet att tjejer i högre utsträckning oroar sig för utsatthet för brott och då främst sexuellt våld. Hotet om det sexuella våldet är inte nödvändigtvis områdesspecifikt utan en del av tjejernas allmänna riskmedvetenhet vart än de befinner sig. Tjejerna uppvisar dessutom en oro för sina killkompisar - att de ska utsättas för brott eller dras med i kriminalitet. Det grundar sig i ett antagande om att unga killar är mer utsatta för brott än tjejer. En av fokusgrupperna resonerade så här:

IP3: Alltså för tjejer i Rosengård alltså det händer typ ingenting. Det är inte så att typ så en kille kommer fram och skjuter. Men för killar förvisso, men de har bröder och så. Det är ändå så... IP1: Riskabelt.

IP3: Ja fattar du vad jag menar men för oss tjejer händer det absolut ingenting. Alltså ingen våldtäkt ingenting sånt där. (Fokusgrupp Rosengård, tjejer 16-17 år) 
Liknande resonemang finns i Sofielund:

IP1: Jag kan också känna att det här med att ehm... jag är mer rädd för kvinnor eller, tjejerna som jag har nära och det är just för det här för att bli påhoppade eller för att bli eh våldtagna. Så jag tycker att där är jag mest rädd för det medans för killarna jag känner, är jag mer rädd för att de ska liksom, som sagt...

IP3: Bli indragna i det.

IP1: ...bli indragna i det eller börja slåss med någon för de tuffar till sig. Speciellt när killar blir tonåringar, du vet, de ska ju bevisa...

(Fokusgrupp Sofielund, tjejer 14-15 år)

Den generella tendensen i materialet är att bedömningen av risken för utsatthet (både personlig och altruistisk) är starkt sammankopplad med huruvida personer också är involverade i miljöer där det finns våld eller rör sig tillsammans med personer som figurerar i sådana sammanhang. Oron för kompisar handlar därför lika mycket oron för att de ska hamna snett som att de ska bli utsatta för brott. Det tycks finns en stark övertygelse om att utsatthet företrädesvis drabbar de som har en viss typ av livsstil, med undantag för sexualbrott som antas kunna hända vem som helst. Ungdomarna lägger därför mycket i sin egen agens - särskilt killarna - att hålla sig borta från de miljöer som anser sig veta är förenat med risk för kriminalitet och utsatthet. En annan strategi som ett antal ungdomar nämner är också att inte lägga sig i utan att sköta sitt för att undvika konflikter. Det kan i sin tur innebära att, som vissa av ungdomarna beskriver det, viljan att ingripa eller att anmäla händelser till polisen inte är särskilt stor. 


\section{SAMMANFATTANDE DISKUSSION}

Sammantaget känner sig ungdomarna i både Sofielund och Rosengård sig trygga i sina områden. Varför är det då viktigt att prata om trygghet i en rapport som handlar om otrygghet och oro för brott? Delvis handlar det om det faktum att "som man frågar får man svar" men också om att otryggheten och oron inte bör överdrivas. Eftersom flertalet ungdomar uppger att de är trygga och initialt har svårt att identifiera problem som skapar otrygghet är ungdomarnas känsla av trygghet ett lika viktigt resultat att lyfta fram som deras resonemang om vad i deras områden som kan ha betydelse för känslor av otrygghet. Det är även viktigt att påpeka att vi i presentationen av resultatet gör distinktioner mellan till exempel platser och vissa fenomen, men det bör tas i beaktande att dessa dimensioner överlappar och att den ena dimensionen ibland är beroende av den andra och vice versa. En plats kan upplevas otrygg på grund av en kombination av faktorer, exempelvis belysningen, personer som frekventerar platsen, och vad som antas försiggå på platsen.

Resultaten från studien visar att det i materialet finns vissa centrala återkommande problem som beskrivs av ungdomarna i båda områdena. Gemensamt är förekomsten av konflikter mellan ungdomar och i viss mån problem med olika grupperingar som finns på offentlig plats. Både i Sofielund och i Rosengård är det vissa specifika platser som förknippas med både problem och otrygghet. I Sofielund lyfter ungdomarna konflikter mellan de olika skolorna i området, narkotika samt den grova gängkriminaliteten kring Seved i Södra Sofielund som centrala problem. Ungdomarna i Rosengård pratade i större utsträckning om skjutningar och annat grovt våld, med stor san- 
nolikhet influerat av mordet på en 16-åring som skedde ganska kort tid innan intervjuerna genomfördes. Varken bruk eller försäljning av narkotika nämndes i någon större utsträckning som ett problem av ungdomarna i Rosengård.

Även om de flesta av ungdomarna vi intervjuat känner sig trygga i sina områden så finns det även indikationer på att de ibland, i vissa situationer och på vissa platser, känner sig otrygga. Det framkommer tydligast i diskussioner om olika riskminimerande strategier och undvikande beteenden.

Mer eller mindre medvetet undviker ungdomarna vissa platser, de har riskminimerande strategier för när de går hem sent (såsom att ta sällskap med andra eller att prata i telefonen) eller beter sig på ett sådant sätt så att de inte ska riskera att reta upp någon annan. Dessa beteenden tenderar att normaliseras och det är inte säkert att ungdomarna själva härleder dessa beteenden till otrygghet. Individer tenderar att normalisera frekvent förekommande, hotfulla fenomen genom användandet av riskminimerande strategier och/eller undvikanden (Carvalho \& Lewis, 2003; Rengifo \& Bolton, 2012).

Det framkommer en del tydliga teman i ungdomarnas erfarenheter av otrygghet. Det finns vissa platser i både Sofielund och Rosengård som återkommer i ungdomarnas berättelser om otrygghet Vissa av ungdomarna undviker dessa platser eller har andra strategier såsom att gå tillsammans med andra eller till exempel ha telefonen redo. De fenomen som ungdomarna beskriver som otrygga överlappar till stor del med de otrygga platserna. I Sofielund finns det en oro för det öppna narkotikabruket där påverkade människor upplevs som farliga och opålitliga. Sofielund upplevs också som en hel del av ungdomarna som folktomt och anonymt, med lite affärer och aktiviteter. Det ger en anonymitetskänsla som tycks skapa viss otrygghet och platser upplevs som tomma och skumma, där "läskiga" människor vistas. I Rosengård är det delvis tvärtom - ungdomarna spenderar mycket tid i Rosengård och de beskriver det offentliga rummet som folkrikt och att det är en plats där "alla känner alla", något som bidrar till att de känner sig trygga där. Men denna sammanhållning kan också skapa otrygghet då alla känner alla och det kan uppstå 
rykten och skitsnack. Ungdomarna i Rosengård beskriver grupperingar som tar vissa platser i anspråk som irriterande och ibland otrygghetsskapande, och framför allt Ramels väg undviks av flera av ungdomarna, men även Bazaaren. Det finns en medvetenhet om att det snabbt kan uppstå bråk kring vissa av dessa platser och både bland killarna och tjejerna vi intervjuat finns strategier för att inte provocera fram bråk eller tjafs. Vissa framträdande problem som beskrivs av ungdomarna i Rosengård, såsom skjutningar verkar inte ha någon effekt på den individuella trygghetsupplevelsen - däremot oroar sig flera över vart samhället är på väg och pratar om risken för att kompisar kan hamna i kriminalitet på grund av att de vistas i miljöer med hög kriminalitet. Liksom för vuxna tycks det snarare som att vardagliga händelser och stressfaktorer, med vissa undantag, är mer avgörande för den enskilda individens reaktioner än allvarligare brott som händer mer sällan (Almeida \& Wong, 2009; Lewis \& Maxfield, 1984). Liknande oro för kompisar - framför allt killkompisar - återfinns även i intervjuerna från Sofielund. Där är det främst tidigare konflikter mellan skolorna i Sofielund som står i centrum. Det finns en medvetenhet om att killar i högre grad riskerar att utsättas för våld i den offentliga miljön. Samtidigt, och kanske lite paradoxalt, uppger flertalet ungdomar att det grova våldet enbart drabbar de som "förtjänar" det, det vill säga de som umgås fel och som kanske begår kriminella handlingar.

Oro för sexuellt våld och sexuella trakasserier återfinns endast bland tjejerna i båda områdena, och oron är sällan platsspecifik utan är istället en något som tjejerna bär med sig oavsett vart de är. Främst oroar de sig för överfall på offentlig plats av okända män, men i intervjuerna lyfts även trakasserier i Rosengårds centrum.

Ett dominerande tema gällande ungdomars otrygghet är män (ofta i grupp) på offentlig plats. Det gäller både killar och tjejer. Samtidigt handlar mycket av tryggheten och känslan av tillhörighet om aktörsskap - att göra platser till sina egna och ta plats i det offentliga rummet (Alexander \& Pain, 2012). Framför allt i Rosengård beskriver både killar och tjejer hur de trots vissa problem med grupperingar ändå nyttjar det offentliga rummet och försöker göra det på sina villkor genom att navigera i de olika miljöerna och mikroplatserna. 
Ungdomarna i Sofielund och Rosengård delar till viss del beskrivningar av problem, erfarenheter av otrygghet och hur otryggheten påverkar dem. Det finns dock skillnader, vilka till viss del kan förklaras av områdenas olika belägenhet och karaktär. Sofielund ligger i centrala Malmö och nära Möllevången, men framstår samtidigt som anonymt och folktomt, framför allt Norra Sofielund. Ungdomarna upplever delar av norra Sofielund som öde med en viss närvaro av "skumma människor". Seved i Södra Sofielund beskrivs av flertalet som ett område med gängproblematik, men få vistades där i någon större utsträckning, om än alls. Rosengård å sin sida beskrivs som sagt av ungdomarna som en plats med mycket folk där "alla känner alla". Majoriteten av de som intervjuats spenderade en stor del av sin fritid i Rosengård. Där verkar snarare bristen på anonymitet kunna utgöra problem och skapa otrygghet, då rykten snabbt sprids och konflikter uppstår. Endast ett fåtal nämnde problem med påverkade människor på offentlig plats eller försäljning av narkotika. De skillnader som framträder mellan de båda områdena skulle också kunna vara ett resultat av skillnader i ålder - ungdomarna i Rosengård är äldre och spenderar troligtvis mer tid på offentlig plats och har kanske mer kunskap om området och grupperna på de olika platserna. Forskning baserad på vuxnas erfarenheter indikerar att ju mer individer tar del av offentlig plats och deltar i både frivilliga och obligatoriska aktiviteter (till exempel arbete eller utbildning), desto lägre är deras oro för brott (Rengifo \& Bolton, 2012). På samma sätt visar tidigare studier att ungdomars otrygghet och oro för brott minskar ju mer de vistas på offentlig plats utan vuxet sällskap (se t.ex. Cops, 2013). Att uppmuntra ungdomars självständiga mobilitet i sina områden kan därför vara viktigt.

En stor del av resultaten är i linje med vad vuxna uppger vara otrygghetsskapande i samma områden (Egnell \& Ivert, 2016) men resultaten bör tolkas med försiktighet. Hittills finns det fortfarande lite kunskap om ungdomars otrygghet, vad i den offentliga miljön som påverkar deras trygghetsupplevelse och på vilket sätt, och huruvida det skiljer sig åt från vuxna. 
Grinshteyn m.fl. (2016) diskuterar möjligheten att områdesfaktorer påverkar vuxna och ungdomar på olika sätt. De fann få samband mellan fysiska ordningsstörningar och oro för våldsbrott bland de ungdomar som ingick i deras studie, och författarna menar att det är troligt att fenomen såsom nedskräpning och graffitti påverkar ungdomar i mindre utsträckning än vuxna. Också ungdomarna i den här studien pratar förhållandevis lite om den typen av fysiska ordningsstörningar, men för att kunna dra några slutsatser kring samband behövs fler och större studier. Det är av stor vikt att öka kunskapen om hur barn och ungdomar upplever och påverkas av att växa upp i områden med olika karakteristika för att - med kunskap förankrad i forskning - utveckla insatser för att öka tryggheten för alla boende och för att säkra barns och ungdomars rätt till trygga uppväxtvillkor. Att i forskningen situera barn och ungdomar som kunskapsbärande subjekt är alltså både ett mål i sig själv och ett medel för att uppnå bättre kunskap om hur samhället kan förbättra barns och ungdomars uppväxtvillkor på lokal nivå. Detta är viktigt eftersom "fear mediates access to resources of all kinds; it sets the conditions for full participation in communities, societies and in life itself." (Alexander, 2009; s. 186).

Den här rapporten har vissa begränsningar och det går inte att dra några generella slutsatser om i vilken utsträckning ungdomar i de båda områdena känner sig trygga eller otrygga, men det har inte heller varit syftet med studien. Urvalet av ungdomar är litet och resultaten bör därför ses som utgångspunkt för vidare forskning. Vikten av att vara försiktig med generaliseringar och slutsatser särskilt inom forskningsområden som är understuderade - kan inte understrykas nog. Variationen i ålder mellan ungdomarna gör också att jämförelserna mellan områdena bör tolkas med försiktighet. Ungdomarna i Sofielund och Rosengård har också rekryterats på olika sätt, vilket kan ha betydelse för resultatet. I Sofielund har vi en enhetlig ålder, och där deltog nästan alla eleverna i de aktuella klasserna. Det betyder att vi kan ha nått ett mer varierat urval. Rosengårdsungdomarna rekryterades via föreningar vilket inte bara skapar variation i ålder, utan det är också möjligt att vi har rekryterat de ungdomar som är relativt trygga, som deltar i aktivitet och rör sig mycket i området. Sannolikt har vi genom vårt urvalsförfarande 
mindre möjligheter att nå de som av olika anledningar inte deltar i aktiviteter - kanske på grund av egen eller vårdnadshavares oro. Fler studier med olika metoder och urvalsförfarande är önskvärt, också i andra områden av staden.

Vi haft som ambition att inkludera ungdomarna som forskningssubjekt snarare än objekt. Beazley m.fl. (2009) menar att forskning med barn snarare än $p a ̊$ barn är ett växande forskningsfält inom många discipliner världen över och att det medför både etiska och metodologiska implikationer. Trots ambitionen att tillskriva barn och ungdomar aktörsskap och definitionsföreträde, karaktäriseras ofta barnforskningen av starka normativa antagen om ålder, menar författarna. Kategorin "barn" homogeniseras, vilket är problematiskt därför att, som författarna skriver, barndomen är en mycket heterogen livsfas där skillnader i ålder kan ha större betydelse än andra faktorer så som kön, religion, bakgrund och andra egenskaper (a.a.). Den här studien inriktar sig på ungdomar i en i en vid bemärkelse - de intervjuade är i åldrarna 14-22 vilket har både för- och nackdelar. Det kan påvisa vidden av ungdomars erfarenheter, men också försvåra jämförbarheten mellan områden och ungdomar eftersom ålder har stor betydelse för hur ungdomar rör sig i sina områden och vad de gör.

\section{Avslutande kommentarer}

Utifrån de resultat som presenterats i den här rapporten och de slutsatser som dras avseende vad som påverkar ungdomarnas trygghet i det offentliga rummet skulle vi särskilt vilja lyfta ett antal rekommendationer med syfte att öka ungdomarnas trygghet i de aktuella områdena.

På offentlig plats i Rosengård och till viss del i Sofielund finns det grupperingar av framförallt unga män som har en inverkan på hur den offentliga miljön upplevs av ungdomarna. Det finns en oro för utsatthet för kommentarer och för konflikter som kan uppstå, en oro som gäller både killarna och tjejerna i studien. Det finns dessutom en oro för att kompisar ska dras in i kriminalitet och gäng. Det behövs insatser på lokal nivå för att aktivera den positiva informella sociala kontrollen, det vill säga att öka viljan och förmågan hos individer att 
ingripa mot beteenden som påverkar ungdomarnas trygghet negativt. Tryggheten kan påverkas positivt om ungdomar och vuxna agerar för att upprätthålla och tillämpa de prosociala normer som redan finns i dessa områden.

Dessutom behöver den ojämlika stratifieringen av kön och ålder på offentlig plats motverkas, och framför allt tjejer behöver stöttas i sitt deltagande på offentlig plats. Tjejernas oro för sexualbrott på offentlig plats, både trakasserier och grövre våld, bör också uppmärksammas eftersom det starkt påverkar var, hur och när tjejerna rör sig på offentlig plats. Här behövs insatser för att gynna agerandet på specifika normer och attityder där sexuella trakasserier och sexualbrott inte accepteras. Det skulle göra att fler grupper - i detta fall unga kvinnor - kan använda den offentliga miljön på lika villkor.

Även om ungdomars självständiga rörelsefrihet på offentlig plats är viktig så finns det samtidigt ett behov av ökad vuxennärvaro i vissa miljöer och situationer. En del av eleverna i Sofielund gav uttryck för att de ville ha fler vuxna i skolmiljön som de kunde prata med om olika saker och vända sig till när det uppstår konflikter i skolmiljön eller i anslutning till skolas aktiviteter. Ett skäl till detta var att det funnits konflikter mellan skolorna i Sofielund. Ökad närvaro av vuxna behöver alltså inte handla om föräldrars närvaro utan kan med fördel vara andra vuxna. Ett sätt att minska eventuella spänningar mellan eleverna från de olika skolorna kan vara att anordna aktiviteter där eleverna möts kring ett gemensamt projekt, så som gjorts i samband med att en cykeltunnel i området renoverades och dekorerades med bilder av eleverna från de båda skolorna.

Något vi särskilt vill betona är att en del av de skjutningar som har skett i Malmö och särskilt i Rosengård där unga människor har varit inblandande starkt har påverkat de ungdomar vi har intervjuat i Rosengård. De utrycker inte oro för att själva bli utsatta (även om risken finns att vara på fel plats vid fel tillfälle) men många är oroliga för vart samhället är på väg och en del känner att samhället sviker dem. Olika aktörer som möter ungdomar i sitt arbete behöver överväga rutiner för hur den här typen av händelser hanteras och av 
vem. Ungdomarna har ett behov av att tala om det som händer, inte bara på kort sikt utan även på längre sikt.

Avslutningsvis vill vi återkomma till det faktum att de flesta ungdomar vi intervjuat oftast känner sig trygga i sina områden. Vi menar att detta kan vara viktigt att ha med sig i det trygghetsskapande arbetet eftersom problemformuleringar och möjliga lösningar behöver bygga på specificitet vad gäller exempelvis platser, personer och tider. Det trygghetsskapande arbetet tjänar inget på att homogenisera områden vars specifika problem och utmaningar skiljer sig ganska mycket åt. Sofielund och Rosengård är exempel på detta. Delar av områdena är klassade som "särskilt utsatta områden" av polisen, men som denna rapport visar så skiljer sig deras karaktär, förutsättningar och källor till otrygghet delvis åt. Att de flesta ungdomar uppger att de är trygga innebär också att det går att bygga vidare på positiva förutsättningar som redan finns i områdena.

Samtidigt som vi vill uppmärksamma att ungdomarna är trygga och ofta rör sig i sina områden utan att känna oro är det viktigt att påpeka att en ökad segregation leder till att en del ungdomar, bland annat en del av de vi intervjuat här, växer upp i miljöer där det förkommer våld och annan kriminalitet i mycket högre utsträckning än i andra områden. En av de huvudsakliga målsättningarna för det trygghetsskapande arbetet måste vara att alla ungdomar ska ha rätt till goda uppväxtvillkor där de i så liten grad som möjligt behöver exponeras för kriminalitet och oroa sig för trakasserier, hot och våld och sexualbrott. Det trygghetsskapande arbetet handlar om att skapa och upprätthålla en offentlig miljö som ungdomar kan utnyttja på lika villkor, inom och mellan områden i staden. 


\section{LITTERATUR}

Alexander, C. (2009). Assembling fear, practicing hope: geographies of gender and generation in Newcastle upon Tyne. (Akademisk avhandling). Durham: Durham university.

Alexander, C. \& Pain, R. (2012). Urban Security: Whose Security? Everyday Responses to Urban Fears. I V. Ceccato (red.), The Urban Fabric of Crime and Fear, (s. 37-53). London: Springer.

Almeida, D. M., \& Wong, J. D. (2009). Life transition and stress: A life course perspective on daily stress processes. I G. H. Elder \& J. Z. Giele (red.), The craft of life course research (s. 141-162). New York: Guilford Press.

Aneshensel, C. S. \& Sucoff, C. A. (1996). The neighborhood context of adolescent mental health. Journal of Health and Social Behavior, 37(4), 293-310.

Beazley, H., Bessell, S., Ennew, J. \& Waterson, R. (2009) The right to be properly researched: Research with children in a messy, real world. Children's Geographies, 7(4), 365-378

Blomdahl, U. \& Elofsson, S. (2017). Jämställd och jämlik! Hälsa och offentligt resursutnyttjande på fritidsområdet bland barn och ungdomar. Stockholm: Stockholms universitet.

Blomdahl, U., Elofsson, S., Bergmark, K. \& Lengheden, L. (2017). Ung livsstil Malmö. En studie av ungdomar $i$ högstadiet. Stockholm: Stockholms universitet.

Brunton-Smith, I., Jackson, J. \& Sutherland, A. (2014). Bridgning Structure and Perception. On the Neighborhood Ecology of Beliefs and Worries About Violent Crimes. British Journal of Criminology, 54, 503-526.

Bryman, A. (2011). Social research methods, 4th ed., Oxford: Oxford University press.

Brottsförebyggande rådet, Brå (2013). Brott bland ungdomar i årskurs nio. Resultat från Skolundersökningen om brott åren 1995-2011. (Rapport 2013:3). Stockholm: Brottsförebyggande rådet. 
Brottsförebyggande rådet, Brå (2016). Skolundersökningen om brott 2015. Om utsatthet och delaktighet i brott. (Rapport 2016: 21). Stockholm: Brottsförebyggande rådet.

Brottsförebyggande rådet, Brå (2017). Nationella trygghetsundersökningen 2016 Om utsatthet, otrygghet och förtroende. (Rapport 2017:1). Stockholm: Brottsförebyggande rådet.

Brottsförebyggande rådet, Brå (2018). Nationella trygghetsundersökningen 2017. Om utsatthet, otrygghet och förtroende. (Rapport 2018:1). Stockholm: Brottsförebyggande rådet.

CAN (2015). Skolelevers drogvanor 2015. (Rapport 154). Stockholm: Centralförbundet för alkohol- och narkotikaupplysning.

Carvalho, I. \& Lewis, D.A. (2003) Beyond Community: Reactions to Crime and Disorder Among Inner-City Residents. Criminology, 41(3), s. 779-812.

Carver, A., Timperio, A., \& Crawford, D. (2008). Playing it safe: The influence of neighbourhood safety on children's physical activity-A review. Health \& place, 14(2), 217-227.

Cops, D. 2010. "Socializing Into Fear: The Impact of Socializing Institutions on Adolescents' Fear of Crime." Young: Nordic Journal of Youth Research, 18 (4): 385402.

Cops, D. (2013). The role of autonomous mobility in public space on fear of crime among adolescents. Journal of Youth Studies, 16(8), 1105-1122.

De Groof, S. (2008) And My Mama Said ... The (Relative) Parental Influence on Fear of Crime Among Adolescent Girls and Boys. Youth \& Society, $39(3), 267-293$

Drakulich, K.M. (2015) Concerns for Self or Family? Sources of and Response to Altruistic Fear. Journal of Interpersonal Violence, 30(7), 1168-1207.

Green, S. (2007). 'Crime, Victimisation and Vulnerability', i S. Walklate (red.) Handbook of Victims and Victimology, s. 91-118. Cullompton, Devon: Willan.

Egnell, S. \& Ivert, A-K. (2016). Flera nyanser av trygghet. (FoU-rapport 2016:2). Malmö: Malmö högskola.

Ferraro, K.F. \& LaGrange, R. (1987) The Measurement of Fear of Crime. Sociological Inquiry, 57(1), s. 70-97.

Finch, H. \& Lewis, J. (2003). "Focus groups", i J. Ritchie \& J. Lewis (red.) Qualitative research practice. A Guide for Social Science Students and Researchers, s. 170-198. London: Sage Publication.

Foster, S., Villanueva, K., Wood, L., Christian, H., \& Giles-Corti, B. (2014). The impact of parents' fear of strangers and perceptions of informal social control on children's independent mobility. Health \& place, 26, 60-68.

Fridh, M., Grahn, M., Lindström, M. \& Modén, B. (2016). Folkhälsorapport Barn och Unga i Skåne 2016 - en undersökning om barn och ungdomars livsvillkor, levnadsvanor och hälsa, Skåne: Region Skåne. 
Grahn, M., Modén, B., Fridh, M., Lindström, M. \& Rosvall, M. (2012) ). Folkhälsorapport Barn och Unga i Skäne 2012 - en undersökning om barn och ungdomars livsvillkor, levnadsvanor och hälsa, Skåne: Region Skåne.

Grinshteyn, E. G., Eisenman, D.P., Cunningham, W.E., Andersen, R. \& Ettner, S.L. (2016). Individual- and Neighborhood-Level Determinants of Fear of Violent Crime among Adolescents, Family and Community Health, 39(2), s. $103-112$.

Hale, C. (1996) Fear of Crime: a Review of the Litterature. International Review of Victimology, 4, s. 79-150.

Heber, A. (2007) Var rädd om dig! Rädsla för brott enligt forskning, intervjupersoner och dagspress. (Akademisk avhandling) Stockholm: Stockholms Universitet.

Heber, A. (2009) "The worst thing that could happen": on altruistic fear of crime. International Review of Victimology, 16, 257-275.

Ivert, A. K., Levander, M. T., \& Mellgren, C. (2015). Den ojämlika otryggheten-Stabilitet och förändring i bostadsområden över tid. Socialvetenskaplig tidskrift, 22(3-4).

Ivert, A.K. \& Torstensson Levander (2014). Adolescents' Perceptions of Neighbourhood Social Characteristics-Is There a Correlation with Mental Health? Child indicators research, 7(1), 177-192.

Jackson, J. (2011) Revisiting Risk Sensitivity in the Fear of Crime. Journal of Research in Crime and Delinquency, 48(4): 513-537.

Johansson, K., Hasselberg, M., \& Laflamme, L. (2009). Exploring the neighbourhood: a web-based surveyon the prevalence and determinants of fear among young adolescent boys and girls, International Journal of Adolescent Medicine and Health, 21(3), 347-359.

Johansson, K., Laflamme, L. \& Eliasson, M. (2012). Adolescents' Perceived Safety and Security in Public Space-A Swedish Focus Group Study with a Gender Perspective. Young, 20(1), s. 69-88.

Kintrea,K., Bannister, J., Pickering, J., Reid, M. \& Suzuki, N. (2008) Young people and territoriality in British cities. Joseph Rowntree Foundation, York.

Kommission för ett socialt hållbart Malmö (2013). Malmös väg mot en hållbar framtid. Hälsa, välfärd och rättvisa. Malmö: Kommission för ett social hållbart Malmö.

LaGrange, R. L., \& Ferraro, K. F. (1989). Assessing age and gender differences in perceived risk and fear of crime. Criminology, 27, 697-719.

Leventhal, T., Dupéré, V. and Brooks-Gunn, J. (2009). Neighborhood Influences on Adolescent Development. Handbook of Adolescent Psychology. 2:III:12. 
Lewis, D.A. \& Maxfield, M.G. (1984) Fear in the Neighborhoods: an Investigation of the Impact of Crime. Journal of Research in Crime and Delinquency, 17(2): 160-189.

Lewis, D.A. \& Salem, G. (1986). Fear of Crime. Incivility and the Production of a Social Problem. New Jersey: Transaction, Inc.

Liamputtong, P. (2011). Focus Group Methodology: Principles and Practice, London: Sage Publications Ltd.

Litzen, S. (2006) Oro för brott i urban miljö. Trygghetsundersökningar med anknytning till Stockholm. (Rapport 2006:1). Stockholm: Kriminologiska institutionen.

Malmö stad (2017). Befolkningshistorik: stadsområde, stadsdel, delområde 2007-2016. (Excelark.) http://malmo.se/Kommun--politik/Fakta-och-statistik/Befolkning.html (Hämtad 180226).

May DC. (2001) The Effect of Fear of Sexual Victimization on Adolescent Fear of Crime. Sociological Spectrum, 21(2), 141-174

Mellgren, C. (2011). What's neighbourhood got to do with it? The influence of neighbourhood context on crime and reactions to crime. (Akademisk avhandling) Malmö: Malmö Högskola.

Office for National Statistics. (2017). Statistical bulletin. Crime in England and Wales: year ending Mar 2017. (Report), Office for National Statistics

https://www.ons.gov.uk/peoplepopulationandcommunity/crimeandjustice/bulletins/crimeinenglandandwales/yearendingmar2017/previous/v1 (Hämtad 180109).

Polisen, (2017). Utsatta områden - Social ordning, kriminell struktur och utmaningar för polisen. Stockholm: Nationella operativa avdelningen.

Rengifo, A. F., \& Bolton, A. (2012). Routine activities and fear of crime: Specifying individual-level mechanisms. European Journal of Criminology, 9(2), 99-119.

Robertsson, H., Begler, E. \& Sandahl, J. (2017). Stockholmsenkäten. Årsrapport 2016. Stockholm: Socialförvaltningen.

Sacco, V.F. \& Nakhaie, M.R. (2001) Coping with Crime: An examination of elderly and nonelderly adaptations. International Journal of Law and Psychiatry, 24, s. 305-323.

Salonen, T. (2012). Barns ekonomiska utsatthet i Sverige. Årsrapport 2012:2, Stockholm: Rädda Barnen.

Sampson, R. J. (2006). How Does Community Context Matter? Social Mechanisms and the Explanation of Crime Rates. I: P.-O. H. Wikström \& R. J. Sampson (red.), The Explanation of Crime. Context, Mechanisms and Development. New York, NY: Cambridge University Press, s. 31-60.

Sampson, R.J. (2012). Great American city: Chicago and the enduring neighborhood effect. London : The University of Chicago Press 
Schreck, C.J. \& Miller, M.J. (2003) Sources of Fear of Crime at School. What Is the Relative Contribution of Disorder, Individual Characteristics, and School Security? Journal of School Violence, 2(4), 57-79

Skogan, W. \& M.G. Maxfield. (1981). Coping With Crime: Individual and Neighborhood Reactions, Newbury Park, CA: Sage Publications.

Spilsbury, J. C., Korbin, J. E., Coulton, C. E. (2012). “Subjective” and “objective" views of neighborhood danger and well-being: The importance of multiple perspectives and mixed methods. Child Indicators Research, 5, 469-482.

Swatt, M.L., Varano, S.P., Uchida, C.D. \& Solomon, S.E. (2013). Fear of crime, incivilities, and collective efficacy in four Miami neighborhoods, Journal of Criminal Justice, 41, 1-11.

Tiby, E. (2009). Stranger-Danger or Fear of the Near? Accounts on Fear of Sexual Abuse, Journal of Scandinavian Studies in Criminology and Crime Prevention, 10(2), s144-160.

Truman, J.L. \& Morgan, R.E. (2016). Criminal Victimization, 2015. U.S. Department of Justice: Office of Justice Programs

https://www.bjs.gov/content/pub/pdf/cv15.pdf (Hämtad 180109).

Van Dijk, Jan, John Van Kesteren, Paul Smit, Tilburg University, UNICRI and UNODC, (2007) 'Criminal Victimisation in International Perspective: Key Findings from the 2004-2005 ICVS and EU ICS'. The Hague, Ministry of Justice, WODC.

Warr, M. (1984). Fear of victimization: Why are women and the elderly more afraid? Social Science Quarterly, 65, 681-702. 


\section{Tidigare utkomna titlar $\mathrm{i}$ serien}

2008:1 Tikkanen, R. Person, relation och situation. Riskhandlingar, hiv-testerfarenheter och preventiva behov bland män som har sex med män.

2008:2 Östman, M. och Afzelius, M. Barnombud i psykiatrin - i vems intresse?

2008:3 Andersson, F. och Mellgren, C. Processutvärdering av "Trygga gatan”. Ett projekt för minskad brottslighet och ökad trygghet i nöjeslivsmiljö.

2008:4 Östman, M. red. Migration och psykisk ohälsa.

2008:5 Berglund, S. Competing everyday discourses and the construction of heterosexual risk-taking behaviour among adolescents in Nicaragua: Towards a strategy for sexual and reproductive health empowerment.

2008:6 Björngren Cuadra, C. Variationens spektrum - en studie av sensibilitet, tillit och vårdetik i hemsjukvård.

2008:7 Mallander, O. Nära Vänskap? En analys av kontaktperson enligt LSS.

2009:1 Hamit-Eminovski, J. Interactions of biopolymeres at biological Interfaces - Examples from salivia and bacterial surfaces. (Licentiatavhandling)

2009:2 Andersson, O. Hållplats 8. En social intervention för unga kriminella i stadsdelen Rosengård, Malmö stad.

2009:3 Johnsdotter, S. Discrimination of certain ethnic groups? Ethical aspects of the implementation of FGM legislation in Sweden.

2009:4 Danielsson, M. Transpersona non grata. Den ogiltigförklarade livserfarenheten.

2009:5 Eriksson-Sjöö, T. och Ekblad, S. Stress, sömn och livskvalitet - en studie bland flyktingar i SFI-utbildning, lärare och handläggare i Fosie stadsdel, Malmö.

2010:1 Gregersen, P. Utopia - utopier som pedagogiskt medel, och deras användning inom akademiskt lärande och kritiskt tänkande.

2010:2 Scaramuzzino, R., Heule, C., Johansson, H. och Meeuwisse, A. EU och den ideella sektorn - en studie av det svenska Equalprogrammet.

2010:3 Björngren Cuadra, C. Kartläggning av preventiva hiv/STI-insatser i Skåne ur ett migrationsperspektiv - AAAQ och grundad tillgänglighet.

2010:4 Tikkanen, R. MSM-enkäten 2008 - Riskhandlingar, hiv-test och preventiva behov bland män som har sex med män.

2010:5 Lindell, L och Ek, A.-M. Komplementära metoder i psykiatriska verksamheter - och brukares upplevelser och erfarenheter.

2010:6 Perez, E. Akademisk yrkeskompetens i socialt arbete - Om socialt arbete i mångkulturella miljöer

2011:1 Berglund, S., Andersson, O. Kihlsten, I., Tengland, P.-A. och Wemme, M. Delaktighet och hälsa. En pilotstudie med ungdomar och beslutsfattare 
i Simrishamn mot hållbara strategier för ökad egenmakt, livskvalitet och jämlikhet i hälsa.

2011:2 Bengtsson, M. och Wann-Hansson, C. Införande av portfoliometodik för professionell utveckling mot yrkesrollen som sjuksköterska.

2011:3 Finnbogadóttir, H. Domestic violence and pregnancy. Impact on outcome and mid-wives' awareness of the topic. (Licentiatavhandling)

2011:4 Johnson, B. Beroendesjukvård och socialtjänst i samverkan.

2011:5 Popoola, M. Lyssna, förklara och förstå. Romska migranters möten med sjukvård i Sverige.

2011:6 Richert, T. Mot en mer kunskapsbaserad öppenvård för unga missbrukare. Slutrapport för ett trestadsprojekt kring erfarenhetsutbyte, kunskapsutveckling och systematisk dokumentation.

2012:1 Richert, T. Hiv- och hepatitprevention på institution. Utvärdering av ett peer-baserat utbildningsprojekt med syfte att öka kunskapen om blodsmittor hos klienter och personal på SiS-institutioner.

2012:2 Mellgren C., Svalin, K., Levander, S. och Torstensson Levander, M. Riskanalys i polisverksamhet. Utvärdering av polisens arbete med riskanalys för våld på individnivå: Skånemodellen och Check 10 (+).

2012:3 Eriksson-Sjöö, T. Utmaningar och bemötande i flyktingmottagandet. (Licentiatavhandling)

2012:4 Nigård, P. Pornografi och sexuell exponering bland unga män och kvinnor. (Licentiatavhandling)

2013:1 Daneback, K., Månsson S-A. Sexuality and the Internet. A collection of papers 2003-2013.

2013: 2 Mellgren, C., Kronkvist, K. Trygghet i lokalområdet: Resultat från Oxie områdesundersökning 2012. Om upplevelser av trygghet, brott och lokala problem.

2013:3 Johnson, B., Lalander, P. Med narkotikan som följeslagare. Femton texter till Bengt Svensson.

2014:1 Perez, E. Vad vet vi om de insatser socialtjänsten gör i hedersrelaterade konflikter inom familjen?

2014:2 Ivert, A.-K. och Kronkvist, K. Kartläggning av den lokala problembilden i Norra och Södra Sofielund - Ett kunskapsunderlag för ökad trygghet och minskad brottslighet.

2015:1 Rasmusson, E-M. ”Ingen har nämnt ordet sex.” Kvinnors och mäns erfarenheter av information om sexuell hälsa vid cancersjukdom. (Licentiatavhandling)

2015:2 Larsson, C., Johnsdotter, S. Sexuell hälsorådgivning i en mångkulturell kontext. Röster från unga svensksomaliska kvinnor.

2016:1 Andersson, M. och Mellgren C. Studenters utsatthet och upplevelser av hatbrott. 
2016:2 Egnell, S. och Ivert, A-K. Flera nyanser av trygghet. En studie av oro för brott i Herrgården.

2016:3 Lindström, P. och Olsson, M. E. Färre villainbrott med märk-DNA? En utvärdering av en försöksverksamhet.

2016:4 Galat, M. Synthesis and characterization of molecularly imprinted polymer receptors targeting the C-terminus of amyloid-beta via epitope imprinting. (Licentiatavhandling)

2016:5 Kronkvist, K. och Martinez Olsson, E. Stöld och inbrott på byggarbetsplatser. Omfattning, skadeverkan och risk.

2016:5 Hjälm, B. Fakulteten för hälsa och samhälle - en framgångsrik historia.

2017:1 Kronkvist, K. och Ivert, A-K. Utvecklingen av brott och otrygghet i Norra och Södra Sofielund. En effektutvärdering av Fastighetsägare Sofielunds arbete.

2017: 2 Levander, S. Fem typer av psykiska störningar som poliser och andra inom rättväsendet ofta möter. Kunskapsbaserade råd om bedömning och bemötande.

2017:3 Wallengren, S. och Mellgren, C. Romers upplevelser av hatbrott: Upplevelser, konsekvenser och stöd.

2017:4 Wallengren, S. och Mellgren, C. Gatans tysta offer: En studie av socialt utsatta EU-medborgares utsatthet för brott, hatbrott och annan kränkande behandling i det offentliga rummet.

2017:5 Takter, M. Vem är den enskilde i ett gemensamt hem? En studie av hur biståndshandläggare förhåller sig till anhörigas möjligheter till frivillighet, autonomi och personlig integritet. (Licentiatavhandling)

2018:1 Andersson, L. och Johnson, B. Valfrihet och egenmakt: En utvärdering av Region Skånes vårdval för LARO.

2018:2 Löfgren-Mårtenson, L., Elmerstig, E. och Tornberg, J. Sex i Syd 2016. Sexuella handlingar och livsstilar i Skåne.

2019:1 Cuadra, C.B. Socialtjänst i ofred: resiliens, beredskap och planering. Ett kunskapsunderlag för den kommunala socialtjänsten.

2019:2 Kronkvist, K., Nordqvist, S., \& Ivert, A-K. (2019). Kamerabevakning i ett särskilt utsatt bostadsområde. Uppfattningar, erfarenheter och effekter av polisiär kamerabevakning med syfte att minska brottsligheten och öka tryggheten.

2019:3 Arvidsson, P. Från policy till praktik: En studie om organisering inom LSS-området. (Licentiatavhandling)

2019:4 Björkhagen Turesson, A., Hjortsjö, M. \& Staaf A. Hemlösa barns vardagsliv i Malmö - Utifrån ett barnrättsperspektiv.

2019:5 Egnell, S. och Ivert, A-K. Ungdomars upplevelser av trygghet och otrygghet i den offentliga miljön: områdeskunskap, vardagsrisker och undvikandestrategier. 

ISBN 978-9I-7877-04I-O (print)

ISBN 978-9I-7877-042-7 (pdf)

MALMÖ UNIVERSITY 20506 MALMÖ, SWEDEN WWW.MAU.SE 